\title{
British Naval Aviation 1908-1914: A Case Study of Military Innovation
}

\author{
James Dorgan
}

\begin{abstract}
This paper examines the development of British naval aviation in the period 1908 to 1914 in the light of modern theories of military innovation. The case is of particular interest because it took place in peacetime in a force which had enjoyed global supremacy for a century, strong contra-indications of the inclination and the capacity for organisational change.
\end{abstract}

The case study examines the development of British naval aviation along two dimensions of innovation: strategy and technology. The analytical tools are the four schools of 'Military Innovation Theory' as identified by Grissom. The evidence is derived from the relatively limited body of secondary material and the archives of the Admiralty, the Air Ministry and the Cabinet. The evidence from these sources seems to indicate that what Grissom refers to as the 'civil military' theory is the most persuasive. This theory was originated by Posen in 1984 and relies heavily on neo-realist approaches to international relations. It holds that while the default position of the military is conservative, the international environment generates challenges which prompt political leaders to insist the military respond. The decisions of the Liberal Government, and especially of Churchill from 1911, seem to reflect this position.

The other theory which offers some purchase is the 'cultural' theory which Grissom associates with Theo Farrell. In this theory the behaviour of the military is determined by values and traditions. In the case of the Royal Navy, the officer corps was technically oriented as a result of education and experience and this facilitated the development of naval aviation. The paper demonstrates that by itself, naval technical competence would not have brought the naval air service to the relatively high level it had attained by August 1914. That required the intervention of the civil authorities responding in the fashion prescribed by the civil-military theory. Culture was facilitative but the neo-realist processes were determinative.

NOTE: This paper is based on an MA thesis completed in the Department of History at Maynooth University (Ireland) and submitted for examination in 2015.

This work is licensed under a Creative Commons Attribution 4.0 International License. 


\section{PART I. INTRODUCTION}

To the man in the street, with a healthy scepticism about all things official, the expression 'military innovation' is a contradiction in terms. Only in the face of disaster and defeat - and not always then - does the ordinary citizen expect much change from the military. ${ }^{1}$ Even academics, who can be expected to be more nuanced, accept the notion as a starting point. Grissom, judges that '... virtually every major study on the subject argues that military organisations are intrinsically inflexible, prone to stagnation and fearful of change.' 2 Stephen Rosen likewise endorses the existence of a consensus on military conservatism: '...it has long been the conventional wisdom that only catastrophic military defeat can prod military organisations into innovation'. ${ }^{3}$

It requires no effort of scholarship or imagination to understand why this might be so. ${ }^{4}$ Armed forces are quintessential bureaucracies being large, authoritarian, and steeply hierarchical. The nature of their mission is such that they cannot be, for example: collegial, as are academic establishments; nor interactive as government agencies are as between different stakeholders; nor yet can decision-making be dispersed as in commercial organisations whose subsidiary units can be left to respond to price signals. Then again, risk and uncertainty loom larger in war, as Clausewitz teaches, than in other forms of human activity, and the best laid plans often go astray. Even in peace, military training and procurement can be complex and hazardous, and mistakes in deployments, equipment choices and organisation, are easily made. Whether in peace or war, when things go wrong the fault is quickly laid at the door of hidebound leadership.

But we are indebted mainly to the academic community for the documented conclusion that, predispositions to the contrary, military formations do innovate, and not simply as a result of disaster. Contrariwise, in some circumstances, defeat is not enough to provoke change. As Farrell and Terriff point out, while acknowledging the fact of military conservatism: '...it is equally true that military organizations can and do change. The historical record of the evolution of military organizations makes this latter claim self-evident.' 5 As change and adaptation are vital processes for the survival of organisations, and the interests that depend upon them, the conditions which produce change in military organisations are of intense academic and practical interest. Consequently, as Till observes, interest in the processes of innovation in general and of military innovation in particular has been increasing - possibly also spurred by the apparent acceleration in the contemporary rate of social and technical change. ${ }^{6}$ The result of this has been an expansion in the volume of academic work on innovation in armed forces drawing heavily on historical materials documenting significant innovations and, equally relevant, the causes of notable failures to innovate.

\section{Naval Aviation as a Military Innovation}

In the years up to the First World War, navies constituted as surface fleets built around large heavily armoured and armed vessels, were challenged by the emergence of two new radical forms of naval power: submarines and aircraft. ${ }^{7}$ The submarine came first and before the War it was clear that it had significantly affected the role of the large 
surface warship as the undisputed centrepiece of naval force. The aircraft came somewhat later but even before the outbreak of hostilities some aspects of air power were considered to have a potentially significant effect on the form of naval power. There were some strong statements to that effect. As Raleigh put it 'the development of the ...aircraft ...promised almost unlimited possibilities of observation and offence from the heights of the air. ${ }^{8}$ Some commentators equated aeroplanes with submarines as jointly heralding the end of big gun ships. Thus Marder quotes Admiral Percy Scott (responsible for the Royal Navy's gunnery) in a letter to The Times in 1914 'Submarines and aeroplanes have revolutionised naval warfare; no fleet can hide itself from the aeroplane eye.' Marder concurs that the War showed that the two had indeed been revolutionary. ${ }^{9}$

This might be an overestimate of the offensive capacity of aircraft initially, but it accurately reflected much expert and public opinion at the time. Certainly long before the outbreak of the Second World War it had become clear that this technology, introduced in the First World War, was one of a triad of more or less co-equal forms of naval power. For Britannia, and any other power that claimed naval supremacy, it was no longer enough to rule the waves; dominion had to be established beneath and above them too. Thus, the development of the Naval Air Service in the years before the First World War was Britain's first step towards controlling above the waves. As such it conforms to the general understanding of military innovation being something which changes the way formations fight, is significant and improves combat effectiveness. ${ }^{10}$

\section{The Royal Navy and Innovation}

It would seem that among the armed services navies are perceived to be as bureaucratic as the other services, or worse. Thus Sumida and Rosenberg: '[n]aval leaders as a group have not infrequently been depicted as technologically conservative and tradition-bound and as such constituting reactionary sub-cultures isolated from surrounding progressive industrial society' ${ }^{11}$; and Jervis '[i]t is a commonplace that navies are even more hidebound than most bureaucracies. ${ }^{\prime 12}$

If that is the case then at the end of the nineteenth century the Royal Navy would have seemed most unforgiving territory for innovation. Its position as the world's greatest naval power was proclaimed by a fleet of battleships that outnumbered the combination of any two of its possible adversaries and a record of invincibility since the eighteenth century. Its position in British life bordered on the reverential as the pediment of Britain's global empire and commerce. In this and in its internal characteristics it had all the contra-indications for an innovative culture associated with military bureaucracies with the addition, in the public mind and its own, of indispensability as the custodian of an impenetrable arcana. In what Sumida considered to be a standard account of British naval policy in the 1900s, he summarises Marder's depiction of the Royal Navy as that of a service 'tactically unprogressive, self-satisfied and thoughtless'. ${ }^{13}$ 
Yet at the end of the nineteenth and the beginning of the twentieth centuries the Royal Navy proved highly innovative in technology, personnel and doctrine. Much of this is associated with the period of office of John Fisher, First Sea Lord from 19041910. Indeed, the boatloads of retired admirals (and some active ones) which put out to publically deplore each of his reforms might give the impression that these innovations were solely attributable to him. But innovation both preceded and succeeded Fisher and his success in office could not have been achieved had his ideas not found fertile ground in colleagues and subordinates and had they not been endorsed by the political leadership.

\section{Historiographical Approaches}

The period has generated a particularly dense historiography mainly because of the Navy's importance as part of the build-up to, or even as a contributory cause of the First World War. Apart from the official navy and air histories by Corbett and Raleigh respectively there is, as already mentioned, Marder's magisterial survey in five volumes. ${ }^{14}$ Historical analyses of the type of Corbett, Raleigh and Marder locate change in external provocations, a perceived threat and civilian intervention. This is characterised by Sumida and Rosenberg as the 'policy and operations' approach to naval history, that is, in their view, the 'methods of traditional political, diplomatic and military history.' But, they argue, this approach to date has '...precluded the application of new and powerful techniques - such as systematic quantitative analysis or interest group behaviour studies that had been examined in other areas of history. ${ }^{15}$ Sumida and Lambert part company with the standard approach, as they characterise it, by harnessing some of the insights of political science as it relates to organisations and interest groups. ${ }^{16}$

Thus, Sumida and Rosenberg argue in the case of the Navy (but applicable to the other armed services), that instead of the 'policy and operations approach' naval history should '... embrace new analytical techniques and research methodologies borrowed from the social sciences, especially those that could be used to sort out complex issues in naval technology, personnel, economics, administration and finance...' ${ }^{17}$ It is within this perspective that academic interest in the phenomenon of military innovation has developed. Samples of the work in this field are contained in, for instance, the volumes edited by Murray and Millet, Winton and Mets, Bryan Ranft and Richard Harding dealing respectively with the interwar period, the period 1918-41, the Royal Navy in 1930-2000 and 1860-1939. ${ }^{18}$

However, according to Grissom, starting with Barry Posen's book, Sources of Military Doctrine in $1984^{19}$ there has evolved a sub-field of academic literature, relying extensively on methodologies from international relations theory, political science and organisation theory. As surveyed by Grissom this 'Military Innovation Theory' has at least four schools of thinking but all are strongly positivist and amount to '...a new social scientific approach to studying how and why military organisations innovate.' 20 Although this approach draws its evidence from historical and near-contemporary case histories, the focus of Military Innovation Theory is not primarily on doing justice to the past in all its complexity and uncertainty - the standard mission of historical 
research. Ultimately, Military Innovation Theory has a functionalist ethos: it aims at identifying the means for managing innovation with the object of promoting military effectiveness. ${ }^{21}$ Till bluntly sets out the innovation research agenda with regard to navies, 'Navies that manage change better, fight better. So we need to know how change - or military innovation - comes about and how it is best managed.'22

\section{Outline of the Argument}

The essence of the methodology employed in this paper is clear enough - at least in intent. The proposition is that there are theories which seek to explain military innovation. These theories are discussed in Part II which follows. The development of the Naval Air Service in the period up to First World War follows in Part III. This is examined in two dimensions: strategy and technology in Parts IV and V. Part VI is then devoted to an evaluation of the explanatory power of the theories in the light of the historical record.

The period of inquiry is not prolonged beyond the outbreak of hostilities. This is not because the factors explored in military innovation theory are overwhelmed by military exigencies. In fact culture, bureaucratic politics, civil and military relations continue to exercise an influence (and incidentally help to explain the occasional absence of innovation in war time). But, as Rosen argues persuasively, in war time everything is different and specifically, unlike peace, military organisations are continuously engaged in fighting, which in peacetime by definition they are not. Conflict provides the necessity and the opportunity to test, evaluate and change equipment, methods and personnel at a rate impossible in peacetime. The challenges of peacetime military innovation are simply different to those in war and it is the former with which this dissertation is concerned. ${ }^{23}$

\section{Source Material}

While the war time activities of the armed services have been intensively studied the peacetime preparations have attracted less attention. And if it is true, as Layman concluded from his researches, '...that the development of naval aviation during the First World War had never been adequately explored', then again the period up to the War was even more neglected. ${ }^{24}$ Histories of aviation, or of the Royal Navy or of the First World War generally start with the airship, note Samson's take off from HMS Africa in 1911, and conclude with a recital of the diminutive establishment in summer 1914 , before getting on to the main business. Grove's Chapter in Benbow is one of the few academic treatments focused exclusively on this period and it is only a chapter of about 10,000 words. ${ }^{25}$

However, official primary resources are relatively rich thanks to the high level interest taken in the fledgling air arm. The main categories of primary material are the 'Admiralty' and 'Air' files in the UK National Archives at Kew. Extracts from many relevant documents have been incorporated in Roskill's compendium for the Navy Records Society. ${ }^{26}$ 
These sources can be supplemented by the memoirs and biographies of the principal dramatis personae involved in the early days of naval aviation such as Fisher and Churchill ${ }^{27}$ but also some lesser figures more directly involved such as Murray Sueter, Reginald Bacon, C. R. Samson, Richard Bell-Davies and A.M. Longmore. ${ }^{28}$ Popular opinion and the views of the various navy and aviation lobbies are catalogued in the papers and aeronautical journals of the time and reflected here in secondary sources. The opinions of another public - though not at variance with popular opinion - is reflected in the debates in the House of Commons.

As noted, secondary sources are not so plentiful on this period. The official histories by Corbett and Raleigh respectively provide helpful background on naval and air developments prior to the First World War, but neither has much to say about naval aviation. This is also true of Volume I of Marder's history of the naval part of the War. More specific volumes are those by R. D. Layman, who has published on both the Royal Naval Air Service and aircraft carriers in the First World War, and include material relating to the pre-war period

There are a number of other volumes, some of them bordering on the realm of 'popular history', which cover the pre-war period including volumes by Arthur Hezlet, Robert Jackson, and David Wrags. ${ }^{29}$ Another sub-genre is histories of types of aircraft, manufacturers or air stations which were focused on the Naval Air Service - what Layman refers to as 'nuts and bolts' books, and which Sumida and Rosenberg class as 'ancillary' history, but which, though historiographically modest, are essential components of the full story. ${ }^{30}$ Altogether, fragments of the story can be gleaned from these sources though, as noted already, Eric Grove's chapter in Benbow seems to be the only academic treatment exclusively focused on the Naval Air Service in the preWar period.

\section{Conclusion}

Military Innovation Theory has evolved in recent years as a branch of military history in response to the perception that change in the military field is accelerating and capacity to innovate is crucial to military effectiveness. The question addressed in this dissertation is how the theoretical field helps to explain the development of aviation in the Royal Navy in the period leading up to the First World War. That development should be instructive in the context of Military Innovation Theory in that the Royal Navy at the time both technically and strategically was built around large surface ships. A further reason for choosing naval aviation in this period is that it has been relatively neglected in naval historiography although primary sources in the form of Admiralty and Air files as well as those of the Committee on Imperial Defence are substantial. The distillation of these is subject to analytical approaches derived from the second element in the literature relied on in this dissertation: Military Innovation Theory. This is addressed in the following Part. 


\section{PART II . THE THEORY: MILITARY INNOVATION}

\section{Civil Military Theory}

As catalogued by Grissom, Military Innovation Theory started in 1984 with the publication of Posen's Sources of Military Doctrine. Posen employs two branches of social science: balance of power theory as elaborated by Theodore Waltz in his neorealist text on international relations, and organisation theory. ${ }^{31} \mathrm{He}$ applies these to three case studies of actual and potential military innovation in the inter-war period to see how they explain certain characteristics of military doctrine: the offensive/defensive features of doctrine; the integration of military doctrine with political ends; and the degree of innovation. The theoretical approach is highly abstract, rather like Waltz's approach to international power politics, but the case studies, which are taken from the 1930s, are very concrete: the development of Germany's Blitzkrieg concept; the Royal Air Force's air defence system; and France's defensive military doctrine. He believes that balance of power theory better explains innovation than organisation theory. Organisation theory would suggest that militaries would not innovate but rather 'escape civilian control in pursuit of their own interests'. 32 But international power politics tends to intrude and when it does innovation is likely to result.

Thus Posen's view is that the default position of military bureaucracies is conservatism. But he argues that while the three militaries did indeed try to escape civilian attention, as tension mounted, they found themselves subjected to political intervention. In the case of Germany and Britain this steered the respective militaries in strategically productive directions. The German leadership, needing quick results, pushed for the development of the Blitzkrieg. The British leadership, concerned with the air threat backed the development of air defences incorporating fighter aircraft and radar. In both cases he contends that this was against the initial inclinations of the respective army and air staffs. In the case of France the political leadership failed, or did not try, to penetrate the military bureaucracy. Posen concludes that the key factor in military innovation is the willingness of the political leadership to intervene, sometimes with the aid of a 'maverick' inside the military sympathetic to the innovation. ${ }^{33}$

Posen's approach has stimulated a number of studies of innovations, identifying political influences outside and 'mavericks' inside the military in the US, Russia and Britain. These are briefly described by Grissom. The conversion of the U.S. Air Force to missiles from planes is credited to pressure from the White House while the Kremlin civil service prodded the Russian military to reformulate its doctrine in the face of changes in NATO doctrines. In a third study Lord Salisbury is credited with ensuring a superior adaptation of the British Army in South Africa than Kennedy and Johnson could secure from the U.S. Army in Vietnam owing to the higher capacity of a British Prime Minister to change his generals - surprising since the Presidents are supposed to be Commanders in Chief while Prime Ministers definitely are not. ${ }^{34}$ 


\section{Inter Service Rivalry}

According to this approach, competition between services stimulates innovation. U.S. armed forces, with their relatively abundant resources and complex structure provides a fertile ground for this type of theorising. Grissom cites a study that explains the U.S. Navy's development of the submarine-launched Polaris missile as a response to the U.S. Air Force's Minuteman land-based missile. Earlier, a similar competition between the Army and the Air Force led to the development of the Jupiter and Thor intermediate range missiles. The Inter-service model can also provide the negative: the absence of competition slows innovation. Thus another study argues that the development of the Trident II, the replacement for Polaris, took place within a stable triad system in which each service had an assured role. Consequently, the Trident spurred relatively little competitive innovation by the US Air Force. On the other hand again, the U.S. Army's acquisition of their own attack helicopters was a bid to pre-empt the U.S. Air Force's acquisition of tactical support resources. However, according to yet another study cited by Grissom, this had the effect of stimulating the Air Force's tactical development in order to avoid losing that function entirely to the Army. ${ }^{35}$

\section{Intra Service Theory}

The inspiration for the 'Intra-service' approach is Stephen Rosen's Winning the Next War: Innovation and the Modern Military and is based on twenty one case studies. ${ }^{36}$ It is a direct refutation of Posen whose notion that innovation requires an external influence and a 'maverick' insider is debunked by Rosen. His review of the cases cited by Posen leads him to quite different conclusions. The core starting point is one central to organisation theory and political science; that military services should not be seen as unitary actors but rather an assembly of structures, levels and beliefs. Innovation comes from competition between different branches within each of the armed services. Within a given service he believes innovation requires a specific alignment of service leaders, mid-level officers and structure to protect innovations. According to Rosen, innovation starts when senior officers develop a new theory of how wars should be fought. The senior officers then recruit more junior officers to their ideology and ensure their promotion up the hierarchy. Typically, this is all done by starting a new branch or arm of the service. Thus, ideology, structure and promotion are mutually supporting. His sample of innovations include air mobile infantry, carrier aviation and amphibious warfare.

Following Rosen, a number of studies have supported his approach. An instance is the establishment of the Specialised Operations Command (SOCOM) in the U.S. Department of Defence. This Command was set up to cover special operations across all services. It offered promotional opportunities for officers transferring in and eventually the Command became its own strongest advocate. Other cases argued in support of the Intra-service model are the development of nuclear gravity bombs, nuclear propulsion and the ballistic missile submarine. The pattern is also supposed to be evident in the Navy's adoption of the Tomahawk cruise missile (which was opposed by the naval aviation service) and was overcome by a coalition between the surface navy community and the submarine branch (which visualised the Tomahawk as an 
enhancement of submarine capabilities). On the other hand a negative case cited is the inability of mechanised infantry to make progress because it falls between two dominant army communities; armour and infantry. The use of the word 'community' in these studies underlines the perception of the armed forces as amalgamations of potentially rival interests not always regulated by conventional bureaucratic authority.

\section{Culture and Innovation}

Grissom considers culture as a factor in military innovation to be the fourth sub-school of military innovation theory. ${ }^{37}$ According to Grissom, the founder of this approach to military innovation theory is Theo Farrell who argues that '...subjective beliefs about the social and natural world defines actors, their situations and the possibilities of action' and that this is a major factor in military innovation. Culture, thus defined, '...sets the context for military innovation and shapes military organisations' reactions to technological and strategic opportunities'. ${ }^{38}$ Culture can be set by senior officers, by external shocks or through cross-service emulation.

An example cited by Grissom is a study which argues that the U.S. Army's Air Land Battle doctrine was an effort by the Army to create a new professional identity in the wake of Vietnam. Kier likewise suggests that French military doctrine between the wars was dictated by a belief, which she claims to have been culturally based, that French conscripts could only execute simple and passive operations. ${ }^{39}$ Another case is that although the U.S. Army's 'Field Manual 100-5 Operations' gave increased emphasis to peace keeping, in fact the Army continued to prepare for conventional war-allegedly a manifestation of cultural predispositions. Farrell himself offers a similar case in the Irish Army. The post-Independence military leadership, having fought a guerrilla war (and then an anti-guerrilla war against their erstwhile comrades) set itself up on British military lines. This was purely a function of the culturallyconditioned aspirations of the officer corps since the new state had no capacity to wage conventional war whereas it had some experience and capacity for unconventional war. ${ }^{40}$ In the case of the U.S. Navy and the Royal Navy at the turn of the century, Mullins argues that innovations were introduced as a result of culture embedded in the officer crops via professional military education. ${ }^{41}$

\section{Bottom Up Innovation}

Grissom, in his review article makes his own contribution to the field by noting that these schools - which he terms the 'major models' - all postulate military innovation as a 'top-down' process and therefore fail to account for instances of bottom-up innovations. ${ }^{42}$ Examples of such innovation include the development of storm troop tactics by German infantry during the First World War and the use of the German 88 $\mathrm{mm}$ anti-aircraft gun as an improvised anti-tank gun by German artillery during the Battle of France. He gives other instances such as the development of Close Air Support (CAS) tactics for the Normandy invasion by relatively junior officers in the face of official apathy. The Uptide anti-submarine tactics developed by the Pacific Fleet during the Cold War is another. Farrell and Russell also give examples of bottom up innovation from Afghanistan and Iraq respectively. ${ }^{43}$ Grissom believes that 
incorporating 'bottom up' type innovations will undermine the major models and lead to their replacement by a unified consensus through a process akin to Kuhn's concept of 'paradigm shift'. 44

\section{Conclusion}

Grissom's survey embraces a considerable volume of academic research and highlights how conventional historical analysis has been enhanced by the introduction of concepts and techniques from the social sciences. Specifically Military Innovation Theory is characterised by a strong reliance on organisation theory, political science and international relations theory. Conflict emerges among the different schools not only in relation to approaches but even in the interpretation of the same historical events. A scan of the literature since 2006 would suggest that Grissom's 'bottom up' contribution has not fulfilled his hope of provoking their replacement by the establishment of a new theoretical consensus - a 'paradigm shift'. Nonetheless the strongly positivist approach of this field has potential for illuminating the phenomenon of innovation in military affairs and perhaps contributing to an understanding of how it can be harnessed to improve military effectiveness. Accordingly, Military Innovation Theory should provide useful tools for analysing the military innovation which was the development of British naval aviation during 1908-14. This is the subject of the next three parts.

\section{PART III. NAVAL AVIATION: CHRONOLOGY.}

The early development of the Naval Air Service, which became the Royal Naval Air Service in 1914, is one of the threads in the tangle of innovation and faltering progress which characterised the early days of British aviation. This embraced aeroplanes and various forms of lighter-than-air vehicles with involvement by private individuals and army and naval 'aeronauts', the service personnel sometimes acting in a private capacity. British pioneers, like their counterparts in other countries, were motivated by a mixture of sporting, adventuring and commercial objectives. But patriotism was also a factor and much private effort and all official interest was to develop aviation with military and naval purposes in mind. ${ }^{45}$

Inevitably this account of the development of naval aviation has to be highly selective and many aspects of its history in its early days cannot be included here. One enforced omission is the organisation of the service vis á vis the Navy itself and vis á vis the aviation branch of the Army. This element of the history of the Naval Air Service in this period is the focus of much historiographical effort, presumably because it bears on the troubling organisational odyssey of the service in the years after 1918 and interservice rivalry with the Royal Air Force. It conceivably does have some implication for innovation and is adverted to in Part VI. But the topic at best seems approximate to the thesis and is not taken up in detail. ${ }^{46}$

\section{Early Years of Aviation: Lighter-Than-Air Craft}

The first military use of aviation was in 1794 when a gas filled balloon was used for observation by the French during the revolutionary wars. ${ }^{47}$ Naval use started in 1806 
when Lord Cochrane bombarded the coast of France with kites launched from his frigate carrying messages calling on the French to surrender. ${ }^{48}$ But these initiatives were soon abandoned and military aviation only became a reality during the brief European wars in in the second half of the nineteenth century and the somewhat longer conflicts in North and South America. ${ }^{49}$ Naval use of balloons emerged around the turn of the century and both Japan and Russia used them during the RussoJapanese War of 1904-5. ${ }^{50}$ Dirigible balloons or airships had to await the development of light weight engines and a major advance came in 1884 when the French Ministry of Defence launched the 165 foot La France powered by an electric engine. However, in 1900 the first Zeppelin, named for its originator, was launched. Unlike other dirigibles at the time, the Zeppelins were rigid and this permitted vastly greater size though at the cost of being difficult to manufacture and manage. While the first Zeppelin crashed, by 1906 the second type had emerged which could travel long distances in reasonable comfort and relative safety. ${ }^{51}$ Thereafter Zeppelin technology developed rapidly in endurance, carrying capacity, speed and, consequently, military potential. Although the French maintained a significant investment in airships, and other countries, including Britain, entered the field, the Zeppelin, and other German made dirigibles, established Germany as a leader in this branch of aviation, which, for what it was worth, lasted until the Hindenburg disaster in 1937.

\section{The Early Years of Powered Flight}

In 1903 the Wrights effected the first powered flight which was something other than a hop powered by nothing more than launch velocity and daring, of which there had by that time been several. But powered aviation only really took off, so to speak, when the brothers flew their aircraft publically in 1908 in the U.S. (Fort Myers) and Europe (Le Mans) and again at a major air show in Rheims in 1909. The Wrights' craft, named the Flyer, was so demonstrably superior to anything else available that the result was, in comparative terms, a stampede by governments and private individuals to acquire licenses to build it (supplemented by others who simply copied it in part or in whole.)

\section{British Involvement in Aviation}

Britain's first modern military experiments with aviation began with balloons in 1878 in Chatham largely as a result of the interest of some officers who supported the work with their own resources in a fashion which presaged the early days of military and naval aviation. However, the Army eventually organised a balloon section and it participated in some colonial conflicts including the Boer War, apparently with encouraging results. Initially at Woolwich the balloon activity was assigned to the Royal Engineers and finally wound up as the 'Balloon Factory' at Farnborough. ${ }^{52}$ The factory's work was exclusively on balloons until 1903 when it started work on a semirigid dirigible for the Army (Nulli Secondus). It had one successful flight over London in 1907 , but it was damaged on the return flight and was never again fully operational.

At this point, Fisher was convinced by German progress with the Zeppelins that the scouting capacity of airships would make them a partial replacement for cruisers. Captain Reginald Bacon, then Director of Naval Ordnance, one of Fisher's protégés, 
submitted a memo proposing the construction of a 'state-of-the-art' airship for the Navy, the Navy's first venture into aeronautics since some kite experiments five years before. Fisher endorsed the memo and the funds were swiftly promised by the Treasury. ${ }^{53}$ However, the craft which emerged, unofficially called the Mayfly, a 660,000 cubic foot capacity rigid craft (about 50\% bigger than the current Zeppelin), was a failure. When it was rolled out it was found to be too heavy and when the frame was lightened the hull cracked. Although technically advanced in a number of respects ${ }^{54}$ the Navy then abandoned airships, though the Army continued with a programme of small semi-rigid airships. As noted, continued progress with airships in Germany and to a lesser extent France, and a report thereon by the Technical Sub Committee of the C.I.D. (see below) prompted the authorities to revisit their decision and in 1912 they decided that after all, dirigibles were important. ${ }^{55} \mathrm{~A}$ programme of cautious construction of small dirigibles and the purchase of larger ones from France and Germany was commenced. Not much progress had been made on this so that by the time the War started the British fleet of airships comprised a total of seven rather small craft.

\section{Development of Aeroplanes in Britain}

During this time Britain was taking its initial steps in aeroplanes but well behind what was happening in the U.S. and France. In 1906 the Balloon Factory had begun to work on aeroplane designs drawn up by Lieutenant John W. Dunne and Samuel F. Cody, two of the larger than life characters that populate the early history of aviation. ${ }^{56}$ By 1909 however, at the time when the authorities sanctioned the development of the Mayfly, R. B. Haldane, Secretary of State for War decided to cancel work on these aeroplane projects and reorganise the Balloon Factory as an aeronautical research and experiment facility, while the private sector would be relied upon to develop the fruits of this research into aeroplanes. Cody and Dunne were permitted to take their half built machines away and indeed the first flight in England was attributed to Cody who managed some short flights in 1908 at Farnborough. ${ }^{57}$ Thereafter many enthusiasts like A. V. Roe made their own aircraft or wealthy individuals such as Frank McClean ${ }^{58}$ and C. S. Rolls had them made for them by specialist manufacturers. An important example of the latter, especially for naval aviation, was Short Brothers which started as balloon manufacturers, mainly for Frank McClean, but later acquired the rights to manufacture the Wrights' Flyer before going on to manufacture its own designs.

With Army encouragement Larkhill, on the Salisbury Plain, became the location for a number of private aviators including C. S. Rolls and the Bristol Company which manufactured its own aeroplanes and provided training for inter alia, army officers in the vicinity. In 1910, in what seems to be the first British military use of aeroplanes, one of the trainees, a Captain Dickson offered his services during the military manoeuvres of that autumn. Also during these manoeuvres, a civilian succeeded in sending a wireless signal from a Bristol aircraft to a station in Larkhill. Military aviation had taken its first tentative steps, all of it as a result of private enterprise or the personal enterprise of army officers. ${ }^{59}$ 


\section{Establishment of Eastchurch: Birthplace of the Naval Air Service.}

Another major centre of aviation was established by Frank McClean at Eastchurch on the Isle of Sheppey. Initially this consisted of an aerodrome for McClean's eclectic collection of aircraft. Since he was an important client of the Short Brothers he encouraged them also to relocate from London to Eastchurch where in 1909 they made six Wright Flyers under licence, before evolving their own designs. Later he leased the aerodrome to the Royal Aero Club (R.A.C.) at minimal cost whose members and training activity concentrated there. As a consequence of this agglomeration of activities a thriving aviation centre started up. Eastchurch is not far from Sheerness on the Isle of Sheppey at the time the home base for the Navy's Reserve Fleet. In late 1910, the R.A.C. offered the Admiralty the use of two planes and Eastchurch for training naval officers in flying for free, provided the Navy picked up the tab for any damage. The offer was accepted and training of four officers including C. R. Samson and A. M. Longmore began in March 1911. About one year after the Army, the Navy had taken its first steps to develop heavier-than-air aviation. ${ }^{60}$

Table 1: Naval Air Service. Aeroplanes

\begin{tabular}{|l|l|}
\hline Date & No. \\
\hline May 1911 & 2 \\
\hline Dec 1911 & 4 \\
\hline April 2012 & 6 \\
\hline Sept 2012 & 12 \\
\hline May 2013 & 34 \\
\hline May 1914 & 55 \\
\hline August 1914 & 93 \\
\hline $\begin{array}{l}\text { Source:Eric Grove 'Seamen or } \\
\text { airmen? The early days of British } \\
\text { naval flying' in Tim Benbow, } \\
\text { British naval aviation: the first } \\
\text { 100 years (London, 2011). }\end{array}$ \\
\hline
\end{tabular}

The arrival of Winston Churchill at the Admiralty in 1911 quickened the pace of development in naval flying in both material and personnel terms. Capitalising on the success of the training of the first four naval fliers he submitted a request to the Treasury for funds for expansion. He ordered the purchase of the two aeroplanes on loan and the acquisition of two more. ${ }^{61}$ More officers were now assigned to training and a corps of ground crew was assembled at Eastchurch. The aerodrome was then classed as a naval air station with Lieutenant C. R. Samson in command. In April 1912, the Royal Flying Corps (R.F.C.) was established with the station at Eastchurch constituted as the Naval Wing to provide specialised training for naval aviators while the Army concentrated at Farnborough. At the end of the year, Murray Sueter, with the rank of Captain, was appointed Director of the Air Department at the Admiralty and effectively head of what was soon unofficially called the Naval Air Service, and in 1914, on the eve of war, formally designated as the Royal Naval Air Service. Further purchases of aeroplanes were sanctioned for the naval service and numbers increased rapidly from 1912 on. (See Table1.).

Meantime, the Naval Air Service began to add air stations along the southern and east coast. One of the first was at Calshot where, under the command of Lieutenant A. M. Longmore it concentrated on the adaptation of aeroplanes and weapons. Between the end of 1912 and August 1914 other stations were established at the Isle of Grain, Felixstowe, Yarmouth and Dundee. When the Naval Air Service acquired responsibility for dirigibles, Farnborough and Kingsnorth were added as airship stations. ${ }^{62}$

The most interesting work, from a historical viewpoint, was trying to accommodate aeroplanes on vessels. Several vessels had been equipped with temporary ramps from 
which aeroplanes could be launched in 1911 and 1912. A more sustainable arrangement was the conversion of an old cruiser, HMS Hermes, into an aeroplane carrier with a hanger at the stern and a launching ramp on the bow. Hermes was paid off before the War by which time the Ark Royal had been ordered as a seaplane carrier, the first ship specifically built to carry aeroplanes. ${ }^{63}$ By the time the war broke out, the Royal Naval Air Service, as it had then become, comprised 93 aeroplanes and seven airships of various types, 50 officers and 500 men, eight air stations and one aeroplane carrier under construction - a dramatic expansion from the four trainees and two borrowed aeroplanes of three years before. ${ }^{64}$

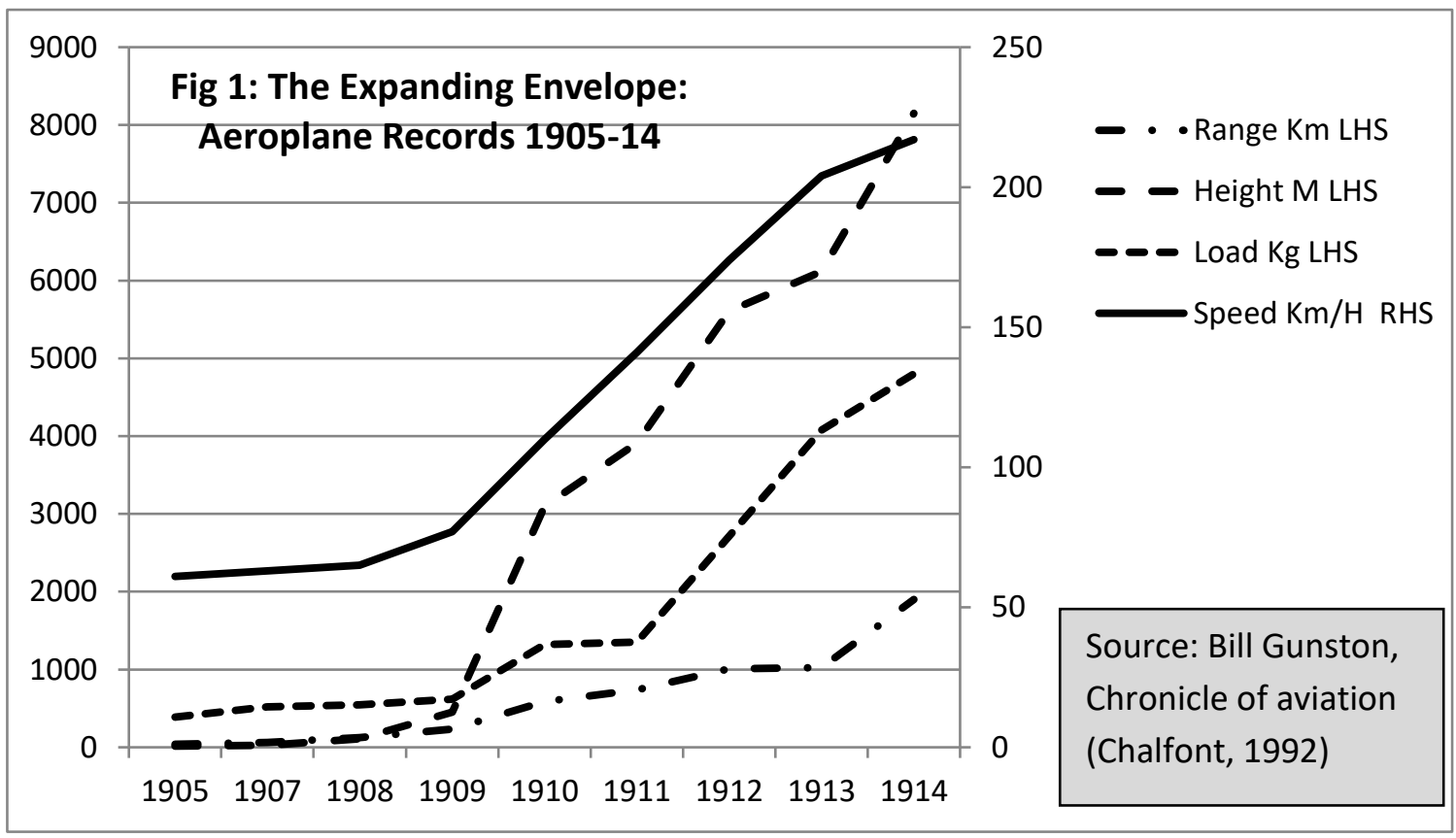

\section{Conclusion}

Military aviation has a long history. But in the 'second industrial revolution' that Azar Gat speaks of (the electro-mechanical one from 1880 onwards replacing the first one based on coal and steam) ${ }^{65}$, aviation developed literally exponentially in the years before the First World War. It was not much more than a decade from 1903 when Orville Wright coaxed his flimsy machine of 605 pounds, 10 feet into the air to run for 120 feet in 12 seconds, ${ }^{66}$ to the time when on the brink of war the protagonists had over 1,000 aeroplanes, the best of which could stretch the Flyer performance 'envelope' by factors ranging from 5 to 500 , depending on what point on the envelope is chosen (speed, altitude, payload, endurance) (See Fig 1 and Table 2). 


\begin{tabular}{|c|c|c|c|}
\hline & Army & Navy & Total \\
\hline Austria Hungary & 47 & 15 & 62 \\
\hline Germany & 232 & 24 & 256 \\
\hline Ottoman Empire & 12 & & 12 \\
\hline Central Powers Total & 291 & 39 & 330 \\
\hline Belgium & 24 & & 24 \\
\hline France & 162 & 14 & 176 \\
\hline Great Britain & 113 & 95 & 208 \\
\hline Russia & 244 & 24 & 268 \\
\hline Allied Total & 543 & 133 & 676 \\
\hline Italy & 86 & 30 & 116 \\
\hline The United States & 28 & 12 & 40 \\
\hline Overall Total & 948 & 214 & 1162 \\
\hline
\end{tabular}

Source: Richard P. Hallion, 'World War I: an air war of consequence' in Endeavour, xxxviii (2014), p. 77.

Initially far behind the French in terms of aeroplanes, the Germans in terms of lighter-than-air machines and the Americans and French in terms of platforms, ${ }^{67}$ the British made up ground so that by the time the war broke out the Royal Naval Air Service, as it had then become, was relatively well prepared in terms of personnel, equipment, organisation and tactics. Indeed Grove concludes that 'Britain's naval aviation developed rapidly to become one of the most progressive air services in the world.' ${ }^{68} \mathrm{~A}$ tradition of innovation in naval aviation was born which endured up to the Invincible class carriers, and the recent Queen Elizabeth class.

\section{PART IV. NAVAL AVIATION: STRATEGY}

\section{Public Interest in Britain}

In the new age of mass media, extensive suffrage and crusading press barons, public attitudes were an important conditioning factor in naval and military matters. ${ }^{69}$ Individual heroism of the pioneer aviators, popular interest and press power made a powerful combination for the projection of patriotic objectives in the sphere of aviation. To these forces were added the more 'respectable' advocacy of the Royal Aeronautical Society (founded in 1866), the Royal Aero Club (founded in 1901) and the Air League of Great Britain (founded in 1909) which focused on promotion of aviation with an explicit military slant. ${ }^{70}$ Some political heft was given to their message by the activities of the cross-bench Parliamentary Aerial Defence Committee under its combative chairman Arthur Lee, Tory MP for Hampshire who served as First Lord of the Admiralty after the War.

Nor should creative fiction be excluded from the mix: H. G. Wells' book, The War in the Air, part of a large literature of military futurism of the time, did much to stoke alarm. ${ }^{71}$ The Zeppelin airships were a focus of particular patriotic concern. Seen as a counter to Britain's naval superiority, they stimulated some excited and very pointed (i.e. anti-British) outbursts among certain parts of the German public to which the British press responded in kind. The impact of Wilbur Wright's first flights in Europe at Le Mans, which took place in August 1908 and were widely reported in the British press, added further to the clamour. Blériot's cross channel flight in July 1909, which 
seemingly ended Britain's insularity, completed a traumatic twelve months for British opinion.

\section{The Sub Committee on Aerial Navigation (SCAN)}

In response to the growing public ferment and no doubt mindful of the Le Mans demonstration and possibly the furore created by Wells's 'War in the Air' 72 , the Prime Minister, Herbert Asquith, requested the Committee on Imperial Defence (C.I.D) to inquire into the threats and opportunities presented by aerial navigation and the resources that Britain should devote to it. The C.I.D. assigned the task to a 'Sub Committee on Aerial Navigation' (SCAN) the importance of which was proclaimed by its membership . ${ }^{73}$ This included Lord Reginald Esher as Chairman, a senior figure in the Liberal administration, Lloyd George, Chancellor of the Exchequer, the political heads of the Army and Navy and the Chief of the Imperial General Staff (C.I.G.S.), General W. Nicholson. The Navy was represented by Captain Bacon who perhaps made up for his relatively low status by being the only member with anything approaching a technical background. Starting on 1 December 1908 the Sub Committee presented its final report on 28 January 2009.

\section{The Report of SCAN}

The Report of SCAN, along with the subsequent discussions at the C.I.D., was the first comprehensive review of the strategic threats and opportunities presented to Britain by military and naval aviation. While the recommendations of SCAN were decidedly low key, and attracted much criticism from historians on that score, ${ }^{74}$ account must be taken of the state of development of aviation at that time. French efforts to fly, while ahead of those in Britain, were inferior to the Wrights' Flyer which by 1908 had only ascended about 50 feet and flown for about an hour after being launched from a kind of catapult. Cody and Dunne's effort to produce viable flying machines had not, at that point, been impressive while two attempts at airship construction by the Army had come to grief. While German Zeppelins had important achievements to their credit they were highly vulnerable (see Section III). Indeed in August 1908 the flagship LZ4, hailed as a giant leap in German airship technology had been wrecked in spectacular fashion, Titanic-like, on its maiden voyage (though unlike the Titanic without any loss of life).

Thus it is somewhat to the credit of SCAN that it did identify and seriously consider many of the eventual strategic functions of airships and aircraft including reconnaissance - the first and most obvious of the potentials of such craft - but also artillery spotting, anti-submarine patrolling, strategic bombardment, fighter defence, troop transport, air dropping of supplies and communications. As Gollin observes, ' The questions asked and the answers supplied ...carried the members a considerable distance. They were grappling with very modern problems. All present were, in a sense, nineteenth century men but they were now at grips with twentieth century themes. ${ }^{75}$ 


\section{Recommendations of SCAN ${ }^{76}$}

SCAN's report consists of six pages comprising a summary and conclusions (i.e. recommendations). At the outset kites and tethered balloons were dismissed as of little use to the military and none to the Navy. On the other hand the evidence considered suggested that dirigible balloons could be used not merely for reconnaissance but possibly also for bombardment, particularly of ships and

Box A. Recommendations of the Sub-Committee on Aerial Navigation

'(a) The Committee are of the opinion that the dangers to which we might be exposed by developments in aerial aviation cannot be definitely ascertained until we ourselves possess airships.

(b) There are good grounds for assuming that air ships will prove of great value to the navy for scouting and possibly for destructive purposes. From a military point of view they are also important.

(c) A sum of $£ 35,000$ should be included in the Naval Estimates for the purposes of building an air-ship of the rigid type. The sum alluded to should include the cost of preliminary and incidental expenses.

(d) A sum of $£ 10,000$ should be included in the Army Estimates for continuing experiments with navigable balloons of a non-rigid type, and for the purpose of complete air-ships or their component parts. As soon as satisfactory results have been obtained with dirigible balloons the expenditure on captive balloons should cease.

(e) The experiments carried out at the military ballooning establishment with aeroplanes should be discontinued, but advantage should be taken of private enterprise in this form of aviation.' dockyards, and of cities with a view to generating civil panic. ${ }^{77}$ Their potential for transporting an invasion force (a function championed by some German popular commentators and feared by their British counterparts) ${ }^{78}$ was considered virtually nil but it was thought that a few might be used to drop small raiding parties capable of inflicting damage on military and naval installations. Aeroplanes were considered something of an unknown quantity but their possible use for reconnaissance was acknowledged, though not by General Nicholson who doubted that anything could be seen from a vehicle, aerial or otherwise, travelling at 30 miles an hour, while C. S. Rolls, at the other extreme, said they could quite easily see submerged submarines and mines. Because of their unreliability it was not thought that aircraft would be useful for operations over the sea. But it was considered that they might have a fighter defence role, in that they might be able to catch and shoot down airships.

The final recommendations are shown in Box A. The gist of them was that the Navy's decision to proceed with an airship was endorsed and the Army should be funded to continue its programme of semi rigid dirigibles at the Balloon Factory. The perhaps surprising feature is the recommendation (e) that aeroplane developments at 
Farnborough be ceased. SCAN pointed out that there were plenty of private individuals and companies working on aeroplanes but airships, being costly items, needed state support. As for aeroplanes what was needed in Haldane's view was a sound scientific basis for aeronautical research. On that basis he cancelled the Dunne and Cody projects, renamed the Balloon Factory the Royal Aircraft Factory (R.A.F.) ${ }^{79}$, made Mervyn O'Gorman, an electrical engineer, superintendent (significantly reporting direct to Haldane, not the Army), and established the Advisory Committee on Aeronautics under the chairmanship of Lord Rayleigh, a Nobel laureate. ${ }^{80}$ Perhaps Liberal laissez faire sentiment had something to do with the decision. It is certainly true that when the R.A.F. became operational there were complaints that it was interfering with private enterprise. ${ }^{81}$ Others believed that state control would deaden rather than enliven research and development. ${ }^{82}$ On balance historians are inclined to the view that Haldane's moves were retrograde and that what was needed was a decisive state intervention in aircraft manufacture. However, Budiansky concludes that in fact the Haldane reforms helped to start the shift of aeronautical superiority from the U.S. to Europe. ${ }^{83}$

\section{SCAN Revisited: Report of the Technical Sub Committee (T.S.C.)}

In 1910, no doubt because of the further development of Zeppelins, aeroplanes, Blériot's flight and continuing public pressure, some of it stirred by Lord Northcliffe, proprietor of the Daily Mail, Esher began to have some doubts about the wisdom of the 1909 conclusions. In October he addressed a note to the C.I.D. suggesting that in the light of recent developments promotion of aeroplanes needed to be reconsidered. ${ }^{84}$ Esher's note produced little immediate result but eventually on 18 November 1911, the Prime Minister requested the C.I.D. to revisit the territory covered by SCAN. The C.I.D. assigned the task to its Standing Sub-Committee which in turn referred it to the Technical Sub Committee (T.S.C.). ${ }^{85}$

The report was tabled on 27 February 1912 and constitutes a fairly dramatic volte face on the SCAN report. First it should be noted that the T.S.C. was composed, as was SCAN, of the higher reaches of the political and defence establishments, including Winston Churchill as newly appointed First Lord, and R. B. Haldane (in the chair) plus Louis Battenberg as First Sea Lord. The C.I.G.S. was absent but there were three other senior army officers. More significant was the participation of one officer with flying experience (Lieutenant C. R. Samson) ${ }^{86}$ and one person with technical knowledge of aeronautical engineering (Mervyn O'Gorman).

The Report pulled few punches acknowledging that 'The sub-committee have been impressed by the evidence which has been placed before them of the backward state of aerial navigation in this country, when contrasted with the progress made by other great naval and military powers.' After noting that Britain had about a dozen operational aeroplanes and two small dirigibles, by comparison with 150 aeroplanes in the case of France and 20 airships in the case of Germany it added that '...the subcommittee have no hesitation in recording their opinion that aeroplanes have now become an important adjunct to the equipment of the army in the field.' 87 It was less certain about aeroplanes and the Navy but concluded that 'It is clear however that the 
Royal Navy cannot afford the risk of dropping behind other nations in this matter, and every facility must be given for experiment and progress'. ${ }^{88}$

The report went on to specify that aeroplane resources of the two services should be combined in one Royal Flying Corps (R.F.C.) with Military and Naval Wings and a Central Flying School (C.F.S.) to be established at Upavon in Salisbury. The Navy was to retain its station at Eastchurch for specialist naval flying and experimentation. In terms of material, the sub-committee recommended the purchase of 25 machines for the C.F.S., 22 for the Navy while the Army's establishment for the seven squadrons was put at 12 machines per squadron or 84 in total.

In terms of airships it reversed the priority in SCAN. Airships seemed not to justify their great cost and it concluded that experimentation by the Navy should be confined to aeroplanes and hydro-aeroplanes. The Army, whose needs were assessed in relation to the continental Expeditionary Force which was visualised in current defence planning, seemed unlikely to need airships, but it should retain the two it already had. ${ }^{89}$

\section{The Revision Revised: Report of Murray and O'Gorman.}

The report was approved by the C.I.D. at its 116th meeting on 25 April 1912. The only significant dissent being that of Churchill who clearly had a change of mind since he approved the sub-committee's report in February..$^{90}$ He now thought that more attention should be paid to airships in the light of advances abroad. In May 1912, Asquith asked the C.I.D. and a slimmed down T.S.C. to reopen the question of airships. In this report the T.S.C. cited communications from the naval and military attaches in Berlin and sundry other information on German and Italian airships. In addition they had the benefit of an in-depth review of airship developments, including visits abroad, undertaken by Mervyn O'Gorman and Captain Murray Sueter passing themselves off to the Germans as Americans. ${ }^{91}$ But behind the scenes Jellicoe, now Second Sea Lord, may also have been influential having been powerfully impressed by a trip in a Zeppelin in 1911. ${ }^{92}$

In a dramatic reversal of their report of a few months previously, the T.S.C. now concluded that 'Their (Sueter and O'Gorman's) report furnishes striking evidence of the progress which has been made on the continent, and particularly Germany in airship development.' The experts believed that Britain was two years behind the Germans and the French and, in short, '...there is as yet no evidence which would afford any justification for further delay in the provision of airships for naval and military purposes.'

The T.S.C. recommended that Britain should aspire to have a modern fleet of airships up to the standard of the best abroad. But after the experience of the Mayfly, the Sub Committee could not recommend building a large airship right away. It suggested that the R.A.F. would build another model of one of the two already in service. While skills were being acquired, German, or failing that French airships could be acquired. ${ }^{93}$

The airship issue had one further significant doctrinal development at political level. At a meeting of the C.I.D. in 1913, Churchill, as noted above now converted to the idea 
that Zeppelins were a major menace, complained that there were no anti-aircraft defences and no flights of aeroplanes and no passive defences (i.e. camouflage). He proposed that the best approach might be to ensure that '.. they were kept away altogether and that would only be done by attacking them' ${ }^{94}$ The proposal was not without effect. In fact the first bombing raid of the war was by R.N.A.S. aeroplanes on Zeppelin hangers in November 1914 (the Friederischafen raid). ${ }^{95}$

\section{Naval Thinking}

At the service level of the Naval hierarchy, somewhat below the political-defence echelon represented by the C.I.D. and its sub-committees, the Admiralty staff were doing some hard thinking on how naval aircraft could be used. The earliest exploration of the implications of air power is probably that quoted by Pugh and is the 1906 address by Sir Charles Campbell to the Royal United Services Institution who envisaged dirgibles being used for naval reconnaissance and also for air to surface bombardment in which capital ships might be vulnerable. ${ }^{96}$ In 1912, the First Sea Lord had been asked by the Secretary of the C.I.D., Rear Admiral Charles Ottley, about the respective roles of military and naval aeroplanes. Ottley suggested that 'The strategical division of the Admiralty should consider in consultation with Captain Sueter and Lieutenant Samson, the strategic use of aeroplanes for naval service... ${ }^{97}$

For the time of writing, early 1912, the Chief of the Naval Staff, Rear Admiral Troubridge gave a reply which was aspirational rather than realistic. ${ }^{98}$ But at least the aspirations were indicative of the developing strategic thinking. He proposed that aeroplanes and some airships needed to be stationed at various places along the North Sea coast where naval operations were likely to be launched and each station should comprise four to six craft capable of wireless telegraphy (W.T.). They would be used for coastal scouting in collaboration with submarines (Royal Navy submarines at that time being designed for coastal patrolling $)^{99}$, destroyers and torpedo patrol boats. He also envisaged that they could be used for attacking hostile aircraft (presumably airships). Aeroplanes should also be embarked on ships, preferably cruisers with a complement of two machines per vessel. Since none of this material existed he went on to recommended ordering airships, aeroplanes and programmes of experimentation with seaplanes and air borne W.T.

A paper circulated by Captain Murray Sueter as Director of the Air Department in the Admiralty gave a somewhat sharper articulation of the Troubridge vision. Although the paper was reported on 29 August 1912, it may have circulated in draft form earlier. ${ }^{100}$ In summary he envisaged naval aeroplanes as functioning in reconnaissance, antisubmarine and anti-mine warfare, counter-reconnaissance (i.e. shooting down enemy reconnaissance aircraft), and air defence of naval installations. He envisaged naval aeroplanes working from land, warships and special 'aeroplane ships'. He proposed the establishment of a chain of 17 aeroplane and airship stations along the east and south coasts. 
The one issue missing from this list was the use of naval aviation in attacking land or sea targets although by then the Naval Air Service was already experimenting with bombing surface targets and some thought, at least, had been given to torpedoes. ${ }^{101}$

\section{Conclusion}

British thinking on the strategic role of aviation followed a tortuous path in contrast to the German and French governments which, from a comparatively early stage, firmly backed lighter-than-air and aeroplane technologies respectively. This is particularly so with respect to airships which were initially widely considered to have vast military potential and which therefore prompted some initiatives by the War Office and the Admiralty. When these produced disappointing results, development was virtually abandoned and Britain was poorly prepared in this area on the outbreak of the War, though it caught up rapidly in semi-rigid dirigibles after war broke out. ${ }^{102}$

But this episode with airships shows that there was nothing inevitable about the development of aviation in Britain. The fact that other countries were backing lighterthan-air technology did not inevitably mean that Britain had to do so. 'Emulation' of international practice, often cited as a cause of domestic policy development in defence and other areas, is not inevitable. ${ }^{103}$ The same could well have applied to aeroplane development. That it did not in the case of the Navy is due partly, to the reflections of the SCAN, the T.S.C. and senior naval personnel on the capacity of aeroplanes for meeting the Royal Navy's specific strategic needs. SCAN's main contribution was the range of strategic possibilities which it canvassed for the use of aviation. While there was no unanimity, the majority view was that a major mode of warfare was opening up with potentially significant implications for the Army and perhaps especially the Navy. By the time the SCAN was reconvened, this time as the Technical Sub Committee of the C.I.D., naval and military staffs, and their political masters were prepared to take ownership of a whole new mode of warfare, including, at least as far as the Navy was concerned, anti-submarine patrolling, coastal defence and air defence as well as reconnaissance.

\section{PART V. NAVAL AVIATION: THE TECHNOLOGY}

While the C.I.D. and the Admiralty, at one end of the hierarchy, were groping towards a viable strategy for naval aviation, at air station level middle-ranking and junior officers, working closely with manufacturers, were developing their own agenda. Indeed, there developed a view in some quarters, according to Pugh, that the Naval Air Service was losing coherence and failing to develop formal doctrine by starting too many experimental 'hares'. ${ }^{104}$ This resonates with Marder's criticism of the Royal Navy as an organisation excessively focused on material to the neglect of strategy and tactics. ${ }^{105}$ But, as Goulter observes, in the early stages of naval aviation when operational experience was nil and technology rapidly evolving, grand doctrines would have been premature and likely to stultify development. ${ }^{106}$ 


\section{Scouting}

In evaluating the development of the Naval Air Service which now took place it has to be borne in mind that coastal defence was a higher priority in the late nineteenth and early twentieth century than it was later when aviation made coastal assaults extremely hazardous. The danger that naval facilities might be bombarded from the sea or that a 'descent' of ground forces might be effected was considered to be high (the 'bolt from the blue' possibility). Consequently considerable resources were devoted to inshore patrol craft like torpedo boats as well as destroyers and submarines. The scouting capacity of naval aircraft, which was the first usage identified for aircraft, was in the context of coastal defences. ${ }^{107}$ The result was that the first expansion of the Naval Air Service was the development of a network of air stations along the North Sea and the Channel coasts.

\section{Anti-Submarine}

Anti-submarine warfare became a specialised branch of naval aviation during the First World War but in 1912 it was one of a number of aspects of scouting. However, it was one which attracted particular priority because of the threat submarines posed to capital ships and because their capacity to submerge made them difficult to locate. Although high hopes were held that submarines and mines could easily be spotted from the air, even when submerged, experiments soon established that this was not normally possible. ${ }^{108}$ of course submarines could be spotted on the surface but it was not at the time thought likely to be much use given that the submarine would be submerged by the time surface vessels could be vectored on to them. ${ }^{109} \mathrm{~A}$ better solution was arming the aeroplane with some kind of anti-submarine bomb. This was pioneering work since it had not been established that aeroplanes could be effective at bombing anything never mind a moving, submersible target. Nevertheless, the Naval Air Service conducted a number of experiments with different types of bomb including the device of dropping a 'stick' of bombs across the path of the submarine. The idea of a depth charge, i.e. a charge exploding at a set depth beneath the surface was mooted in 1912 but did not become a reality until 1916 and then only for ships. ${ }^{110}$

\section{Fleet Scouting}

A natural evolution of coastal scouting was the use of aeroplanes for scouting for fleet operations. The range of aeroplanes at the time (about 50 miles) meant that special aeroplane carriers would have to be built and that aeroplanes had to be capable of taking off and landing on the sea (being craned out and in) from the carrier. Obviously, it would be better still if the aeroplanes could be launched from ships. The problem of landing on ships was not solved until 1917 and required a radical change in ship design. The first aviator to take off from the sea was a Frenchman Henri Fabre in $1910 .{ }^{111}$ The first British aviator to do it was Lieutenant Swann in November 1911. Typically enough this was a private venture: the plane was his own, an Avro $D$, and the floats had been made with the proceeds of a 'whip around' of his brother officers of HMS Hermione and their wives. ${ }^{112}$ Attempting to land on water after his take off, Lieutenant Swann crashed - hardly surprising, since this was his first flight! The honour of landing on 
water other than by crashing went to Lieutenant A. M. Longmore who devised airbags for the purpose with the aid of Short Brothers. ${ }^{113}$ Longmore's invention was of limited use since take off was impossible with the bags: floats were the way forward. The achievement of both landing and taking off from water was claimed by Commander (as he had become) Samson in April 1912. ${ }^{114}$

Taking off from ships presented different challenges. An American flier had accomplished this in November 1910 from the USS Birmingham in Hampton Roads and in January 1911 he landed on the USS Pennsylvannia in San Francisco Bay. ${ }^{115}$ But on both occasions the vessel was at anchor. In December 1911, in a Shorts S.27, Samson succeeded in taking off from a specially constructed ramp over the forward turret and foredeck of HMS Africa, a battleship, anchored in Sheerness harbour. However, he repeated the feat in May 1912 on HMS Hibernia at the naval review at Weymouth when the ship was doing 10.5 knots. ${ }^{116}$ Constructing ramps on first class warships was considered expensive, since it incapacitated half of the main armament and Troubridge's vision of aeroplane-carrying fleet cruisers was not realised - at least not until well into the War. ${ }^{117}$ In the meantime, as described in Part III, the Admiralty made do with the Hermes and later the Ark Royal.

\section{Wireless Telegraphy}

Wireless Telegraphy (W.T.), then in its infancy had the obvious capacity to magnify the effectiveness of scouting through shortening the time between observation and report, an interval of particular importance in sea warfare given the ability of vessels to change position rapidly. However, W.T. equipment was relatively heavy, required a special operator, could only transmit and the range was limited. With their greater capacity for payload, including the weight of a dedicated operator, airships were the first aircraft to be equipped with W.T. But experiments with aeroplanes followed very rapidly and improvements both in wireless technology and in the capacity of aeroplanes led to them being added to some naval aeroplanes. One of the first aeroplanes to be equipped with W.T. was the Shorts S.27 in which Commander Samson had flown from HMS Africa and Hibernia. ${ }^{118}$ In the 1912 naval exercises at Weymouth, a Short seaplane (S.41) was fitted with a transmitter and attained a range of 3 to 5 miles. By June, after some more work, Samson reported that the range had been extended to 10 miles. ${ }^{119}$ By the end of 1913, 16 naval aeroplanes were fitted with wireless sets with ranges up to 45 miles. ${ }^{120}$

\section{Naval Air Activities}

In 1912, Samson and Longmore attended the naval manoeuvres of that year. They do not seem to have flown scouting missions but rather demonstrated bombing, taking off from ships and the use of W.T. Navy pilots also participated in the Army manoeuvres of 1912. ${ }^{121}$ In July 1913 a more substantial demonstration was carried out during manoeuvres involving two fleets of a total of 351 ships. Two seaplanes were embarked on HMS Hermes, the converted cruiser already referred to, and attached to the 'red' fleet (defending). One of these was damaged at an early stage and replaced. The other was a Shorts seaplane (in fact Shorts S.81 with Shorts-patented folding 
wings) and flown by Samson. It was operational from the start of the exercises and carried out seven missions between 21 July and 1 August when it was downed in the sea by mechanical failure. The land based planes, ten in all for both fleets, also carried out a number of missions and spotted submarines and surface vessels. One observation by a 'blue' aeroplane was judged to have resulted in the 'loss' of a 'red' submarine - a significant event in naval aviation history. It would seem that the aeroplanes had played a valuable part in the exercises and the investment in this technology had been vindicated. ${ }^{122}$ One other important feature of the exercises was the use of W.T. The Shorts aeroplane had a French-made Rouzet wireless and used it throughout the exercise. After coming down, and when the aeroplane was apparently lost, the W.T. operators on Hermes were able to indicate the approximate direction and distance of its last transmission. This aided the recovery of the aeroplane and its crew. $^{123}$

\section{Fighter Defence}

The value of aerial scouting of naval facilities and the perceived threat of bombardment by the Zeppelins led to the evaluation of aeroplanes in a fighter defence role. Initially there was some doubt whether aeroplanes or airships would be best at air defence. ${ }^{124}$ There was also some consideration by a Committee under Murray Sueter of the value of camouflage. But tests of this by his pilots yielded negative results. ${ }^{125}$ The increasing speed and payload of aeroplanes, plus Britain's ongoing difficulties with lighter-than-air technology, therefore focused attention on the capacity of aeroplanes as fighters. Under the direction of Lieutenant Clark-Hall experiments were carried out at Calshot with guns of varying calibres from pistols up to and including 1.5 pound artillery. ${ }^{126}$ The latter weapon weighed 265 pounds and, according to Longmore was tested successfully on a Sopwith. Later it was transferred to a Shorts Brothers S.81 on which it was demonstrated during the Naval Review of 1914. ${ }^{127}$ 'Success' was clearly qualified: the recoil of the 1.5 pounder was such that it threatened to shatter the aeroplane and, in any case, brought it to a horizontal halt which necessitated a sharp dive before the aeroplane could regain flying speed. ${ }^{128}$ After extensive tests with floats and kites as targets it was concluded that machine guns offered the best chances of hitting a moving target from an aeroplane. Consideration was also given to dealing with Zeppelins by dropping bombs or hand grenades on them or trailing a grappling iron to rip the envelope. In fact, fearing some kind of pre-emptive strike from massed Zeppelins, on the brink of war Churchill ordained that the primary purpose of naval aeroplanes was fighter defence and not scouting. ${ }^{129}$

\section{Bombing}

Consideration of bombing land targets, such as shipyards, docks, and vessels at anchor emerged at official level in 1913. ${ }^{130}$ A particular focus of concern at this level were the Zeppelins and, as noted above Churchill suggested that attacking them in their sheds by bombing might be the most effective form of defence. In fact by then the Navy had considered the potential of naval aeroplanes for bombing submarines. In March 1912 Samson dropped a 100 pound 'bomb' from a Short biplane at Eastchurch, the first such 
test by a naval aviator. Until the test, there had been concern that the release of the bomb would destabilise the aeroplane. That point satisfied, a number of other tests followed at Eastchurch including the designs of aerodynamically efficient bombs, bomb sights and the stick of bombs technique already referred to. ${ }^{131}$ It was in the context of this work that a naval officer, Lieutenant Travers, came up with a bomb sight capable of automatically calculating the speed of the aeroplane relative to target and automatically releasing the bomb over the target. The device was widely used by the Navy and the Army until 1916. ${ }^{132}$

\section{Torpedoes}

According to Goulter, as early as 1911 naval officers had been thinking about the more difficult task of attacking a vessel at sea by using a torpedo. Carrying massive explosive power, the torpedo was one way for aeroplanes to tackle large ships. The problem was, of course that even the 14 inch torpedo, which could only deal with cruisers and lesser vessels, weighed 810 pounds which stretched the pay load limit of aeroplanes of that time. The project was pushed ahead by Sueter who invited Tommy Sopwith, founder of the Sopwith company, to design an aeroplane capable of carrying a torpedo while Sueter invented a release mechanism. ${ }^{133}$ The work encouraged Churchill to report to the C.I.D. that success was imminent and indeed an order had been placed for an aeroplane to carry an 18 inch torpedo. At this point Churchill visualised torpedo bombers being stationed along the coast to function alongside other torpedo-carrying coastal craft: torpedo patrol boats and submarines. ${ }^{134}$ In the event, Sopwith's designs were not a success until 1916 and credit for the first torpedo drop went to A. M. Longmore in a Short S.184 aeroplane at Calshot in July 1914 with a rig designed by Horace Short and a release gear designed by Lieutenant Hyde-Thomson. ${ }^{135}$ Later, although he claimed the torpedo ran 'true', Longmore dismissed the achievement as no more than a 'stunt', apparently because the lightening required of the aeroplane limited its range. ${ }^{136}$ Nonetheless, it was a significant step and by the start of the war the Navy had a functioning torpedo aeroplane. ${ }^{137}$

\section{Conclusion}

From the start, at the level of middle and junior service personnel, in the Navy, there had never been any doubt that a new era was dawning. Through exploits of daring and technical ingenuity before and certainly after the report of the SCAN, they created what might be called 'facts in the air'. Thus young officers, and sometimes civilians, tinkering with machines and instruments, pioneered the technicalities of flying on and off water, and off vessels, as well as air-borne W.T., fleet scouting and anti-submarine patrolling, fighter defence and bombing. Unlike the Army, which relied mainly on the R.A.F., the Navy developed close relations with a number of manufacturers, notably Shorts, Sopwith and A. V. Roe. It is clear from memoirs that much of the work was carried out by the officers themselves, working side by side with technicians. ${ }^{138}$ 


\section{PART VI. ASSESSMENT}

\section{Civil Military Theory}

The historical evidence would seem to suggest that Posen's theory of Civil-Military relations has some explanatory power in the development of the Naval Air Service in the period up to the outbreak of war. According to Posen, relying on 'balance of power' theories of international relations, relations between states are essentially rivalrous and this dictates the shape of national alliances and the structuring of military and naval resources. The relationship between international relations and the armed services is mediated by strong minded political leaders confronting service chiefs with political realities.

The evidence of the reports of the Committee of Aerial Navigation (SCAN) in 1909 and the Technical Sub Committee (T.S.C.) of the C.I.D. in 1912, together with the related correspondence and C.I.D. minutes sheds considerable light on the relationships between the politicians and the service chiefs, since representatives of both sat on these committees. In the first case, Sir John Nicholson, the C.I.G.S. and his army colleagues strongly denied that aeroplanes had anything to offer. It may be that SCAN's conclusions were influenced by Sir John and the army colleagues that he rounded up in the Appendices to query the utility of aeroplanes. ${ }^{139}$ But in fact while not exactly facing down the generals, the political leadership proceeded with the development of aeroplane technology. As it happened, the reorganised R.A.F. did most of its work for the Army, but its impact on general aeroplane development, as well as the other Haldane reforms formed part of the infrastructure for the Navy's suppliers. ${ }^{140}$

By the time the T.S.C. got down to work in 1911, the formidable personality of Churchill had become First Lord. As something of a 'techie' in today's terms, Churchill was an ardent enthusiast for aviation and spent a lot of time at Eastchurch, sometimes going aloft with naval fliers. ${ }^{141}$ Naval chiefs like Battenberg and Jellicoe seemed to be reasonably well disposed to naval aviation while others who might have been sceptical would have been disinclined to argue about it with their opinionated political chief. However, there was one issue on which the naval political and service chiefs did come into open conflict. The First Sea Lord, A. K. Wilson was sceptical of airships while Churchill, as already noted, was not. There was a long and argumentative exchange between Wilson and Churchill on the matter in which Churchill had the better turn of phrase but Wilson had the better point. ${ }^{142}$ Notwithstanding that, the Admiral did not win the battle: the Admiralty proceeded to buy airships and in 1913, furthermore, it took over the Army's airships, thus furnishing some support for the Posen thesis. Indeed Marder does assign to Churchill an important role in the promotion of naval aviation and in helping the Navy to be ahead of the Army in strategic thinking about aeroplanes, citing Churchill's speech to the House of Commons on 17 March $1914 .{ }^{143}$

Moreover, perhaps at the price of some distortion to Posen, it may be that civilian intervention can take forms other than through political leaders. The record suggests that there were at least two other candidates for the role of 'civil intervention' in the 
case of the Naval Air Service. At one level, there was pressure from the general public, including in this the electorate, the press and some of the national lobby groups already cited. In Britain's democracy, at that time, interest in defence matters was intense and in aviation matters it became progressively more aggressive especially as Britain's relatively weak position was very obvious. The public was well informed about Zeppelins ${ }^{144}$ and in any case they could see, because they attended air shows in large numbers, that Britain lagged behind the French in air races and endurance tests where the French carried off the prizes. ${ }^{145}$

Civilian intervention can also be constituted from the large numbers of civilian pioneers - 'pioneer publicists' - who took on themselves to push and stimulate the two services to take aviation seriously. It has already been recorded that much service aviation started with civilians such as C. S. Rolls in the case of the Army and Frank McClean in the case of the Navy providing training and aeroplanes for service use on a gratuitous or heavily subsidised basis. The activities of civilian pilots as 'pioneerpublicists' like Grahame White and Cecil Grace, buzzing the dockyard at Sheerness and the fleet at Mounts Bay and Torbay in 1910, and Frank McClean flying through Tower Bridge and under the Thames bridges to fetch up outside the Houses of Parliaments in his seaplane in 1912, were 'stunts' performed by civilians but calculated to provoke the services into taking aviation seriously. The zenith of this kind of 'lobbying' was surely Grahame-White's demonstration of military flying at Hendon in May 1911 This was in front of the Prime Minister, the Secretary of State for War and 300 M.P.s. The demonstration included 'bombing' a model of a battleship from 2,000 feet. ${ }^{146}$

Finally, it might be added, that to the extent that the Civil-Military theory needs a 'maverick', meaning an independently-minded advocate of naval aviation, the pre-War Naval Air Service had one in the form of Murray Sueter. Sueter had a strong technical background having worked on submarines, fire control systems, airships, aeroplanes, armoured cars and tanks. Under his leadership the Naval Air Service - which was his designation of the Naval Wing of the R.F.C. - developed semi-independently from the Military Wing of the R.F.C. in organisation and strategy. ${ }^{147} \mathrm{His}$ maverick tendencies continued but took a less constructive direction as the War progressed and he left the Navy under a cloud, being finally forgiven and knighted only in 1934. ${ }^{148}$

\section{Inter Service Rivalry}

What Grissom calls the 'Inter-service' model of military intervention appears to have little relevance to the evolution of aviation in the pre-war period. This approach would suggest that the two services would promote rival technologies, or rival projects, in an effort to win roles and resources. It is certainly true that both services had a strong, if not always consistent, interest in the lighter-than-air and aeroplane forms of aviation. Nor were resources overly abundant because of the growing political resistance to increasing defence, especially Navy budgets. The political expression of this was found in the Liberal Party and especially among socially progressive leaders such as Lloyd George. The $f 25,000$ which the Balloon Factory (as it then was) spent on Cody and Dunne's projects was considered by Haldane to be excessive and a main reason cited for their cancellation. Even in those days such a sum was not enormous in absolute 
terms (a light cruiser was estimated to cost $f 200,000$ ) thus underlining that at that time, at least, budgeting was tight. ${ }^{149}$

However, conflict was avoided for a number of reasons including timing, organisation and strategy. The timing factor was evident in relation to airships. The Army's interest in airships was cooled after the failure of the Nulli Secondus which was the moment when the Navy began to promote the project of the Mayfly. The C.I.D. was not then faced with rival demands from the two services for essentially the same technology. From 1912 onwards, the purse strings were loosened and the T.S.C. had little difficulty in recommending large scale purchases of aeroplanes and airships thereby removing any possibility of a conflict between the two branches of aviation.

Secondly, the Army and Navy had different visions for the use of aeroplanes. The Army expected that aeroplanes would function exclusively as scouts for the Army's projected continental Expeditionary Force; it did not at that time have a vision of the aeroplane serving any other function. The Navy had the same aeroplane scouting mission for activities at sea. But because of the perceived threat of Zeppelins to onshore naval facilities, the Navy had also visualised a fighter defence role. The Zeppelin threat was furthermore the reason why the Navy was groping towards a strategic bombing function and considering the destruction of Zeppelins on the ground - given the acknowledged difficulty of catching them in the air over the numerous and scattered naval facilities. Experiments with aeroplanes as anti-submarine and anti-ship platforms were further naval diversifications which had, at that time, no military equivalent.

In sum, the kind of conflict which is documented by Grissom in the case of the U.S. armed services did not exist in Britain. The innovation that did take place was not attributable to any kind of competition between the two branches. There was plenty of work for both services and, as war drew near, financial resources were adequate.

The third dimension of the issue concerns organisation. The formation of the Royal Flying Corps (R.F.C.) in 1912 brought military and naval aviation into one organisation. Also the Central Flying School (C.F.S.), a key element in the structure, was intended as a facility for both. It might be recalled also that it had been intended that the Royal Aircraft Factory (R.A.F.), constituted in 1909, would be a technological powerhouse for all types of aeroplanes. The Air Committee, as a kind of Board of Directors, was set up to integrate the two services, with representatives of the Navy and Army 'shareholders'. In other circumstances, the new structures would have been the locus of intense rivalry. In fact the Navy mostly went its own way leaving the R.F.C. by default a military organisation. Likewise, the R.A.F. became, in effect the Army's inhouse aeronautical ' $R \& D$ ', and developed a number of aeroplanes for the Military Wing ${ }^{150}$ while the Navy continued its relationship with Short Brothers, A. V. Roe and Sopwith. There was no competitive rivalry between the two because, in effect, their paths never crossed. It hardly needs to be added that matters did not continue like this after the War started and the Navy eventually lost out to the (much larger) Military Wing during the War, at some cost, it has been argued to technical development. ${ }^{151}$ 


\section{Intra Service Theory}

Rosen's Intra-service model does have a degree of resonance in some of the innovation that took place during John Fisher's time in the Admiralty including his term as Second Sea Lord (1902 to 1904) as well as the period as First Sea Lord (1904-1910). Fisher certainly developed '....an explanation of what the next war will look like and how officers must fight it if it is to be won' as Rosen put it. ${ }^{152}$ Amongst other things he realised the need for new technologies. Notoriously, he used the other feature of Rosen's theory of innovation: the recruitment of promising officers to the innovation (be it strategic, tactical or technological) through what Rosen calls 'promotion pathways'. In Fisher's case these officers were members of Fisher's famous (or infamous) 'Fish pond', a kind of naval masonry consisting of Fisher's protégés. This does seem a satisfactory explanation of the Mayfly project. Fisher imagined that airships were a new form of cruiser, but cheaper, and used Bacon, a protégé from Fisher's time in the Mediterranean, to promote and develop them.

At this point Rosen's theory encounters some turbulence. The Mayfly proved not to be a successful innovation and was dropped. Moreover, it is not clear that this process applied during the development of naval aeroplanes. In fact, the service chiefs who followed Fisher wilted under the overwhelming personality of Churchill as First Lord and were hardly long enough in office to undertake any significant innovation - much less shape the officer corps to support it. ${ }^{153}$ Not that any innovation was needed from the Sea Lords in the matter of naval aviation since Churchill was an enthusiast. In other words, if anything, so far from Rosen's approach, it is Posen's theory of innovation resulting from extraneous civilian intervention which is confirmed as more appropriate.

\section{Culture and Innovation}

That culture might be an explanatory factor in the development of the Naval Air Service can be gauged by comparing the Navy and Army approaches to aviation. In her appraisal of naval aviation Goulter notes the superiority of the R.N.A.S. to the Military Wing of the R.F.C. and later the Royal Air Force, which the former Military Wing came to dominate, in terms of strategic thinking and technical development. In her 1995 work she unfavourably compares the Military Wing's approach to navigation, flight training and technical development with that of the Navy. In effect the Army had no means of navigation other than using the Bradshaw Railway Guide to follow railway tracks; training was half as long as in the Navy; aeroplane testing was negligible and the Army made no inputs to development at the R.A.F. unlike the interactive relationship between naval officers and Navy suppliers. ${ }^{154}$ Things did not improve after hostilities broke out. In her 2002 article, reflecting on the first years of the war she repeats 'These examples (R.N.A.S. bombing strategy, navigation and bomb aiming technology) demonstrate to what extent the R.N.A.S. was at the forefront of aviation science'. Noting that the Military Wing did little research and development, she concludes that in the new Royal Air Force, 'There was nothing to replace the Navy's strong R\&D tradition.' ${ }^{155}$ This view of the technical superiority of the Naval Air Service is endorsed by Jones, especially with regard to bombing and bomb aiming. ${ }^{156}$ 
More generally, the technical superiority of the Naval Air Service seems to be borne out by a comparison of the records of the Air Committee which had been set up in 1912 as an overall coordinating body. In its annual reports in 1913 and 1914 it records more intense 'experimental work' by the Naval Wing with regard to gunnery, bombing and W.T. than in the Military Wing. ${ }^{157}$

Of course there are objective factors in the Navy's performance in some of these areas. One would expect the Navy to be more advanced in navigation than the Army. No doubt naval flying, being mostly over water, is more demanding than flying over land. But the observed discrepancy between the two services was large and there is no substantive reason why, at the minimum, the Army should be inferior to the Navy in bombing and aeroplane development.

One is left to explore the different levels of professionalism in the naval and military traditions, particularly in relation to technology. The Navy was 'material intensive', the component of vessels, engines, guns, in relation to human resources was higher than in the case of the Army. Naval education took longer and officers underwent demanding training in mathematics and science. Career avenues in the Navy were often via technical specialities like engineering, gunnery and torpedoes. ${ }^{158}$ From 1890 onwards, the Navy had been subject to a series of technical revolutions in these areas, as also in strategic thinking, leading to new concepts in vessels such as the dreadnoughts, battlecruisers and submarines. All this bred what might be termed an 'innovation friendly' culture which made naval officers at all levels comfortable with the exploitation of aviation. ${ }^{159}$ Indeed, some historians have suggested that the Navy was excessively technical (a dimension of the material-intensive mentality referred to above) to the exclusion of tactical and strategic thinking. ${ }^{160}$

\section{Conclusion}

Of the four schools of thought which have been discussed in this dissertation within the field of Military Innovation Theory, it is Barry Posen's Civil-Military model which seems to have the greatest explanatory power. It will be recalled from Part II that Posen set his theory in the wider context of balance of power theory - a derivative of modern, specifically 'neo-realist' international relations theory. International relations, which are essentially competitive according to the realist view, are the overarching influence in defence postures. International relations in the period 1900-14 conformed exactly to the realist view, and in addition, because of the multiplicity of 'players', were inherently, and as it proved disastrously, unstable.

The Cultural approach also seems to have some explanatory value. But a fundamental problem is that there is a contingency in the Cultural theory - at least as manifested here - in that a disposition to make and a capacity to explore a technical innovation does not necessarily make for a military innovation. 'Build a better mousetrap and the world will beat a path to your door' is a well-known saying but indicates only that at the time it was coined mice were considered to be a problem and cats were in short supply. Innovation is a more complex process embracing strategy, tactics and organisation as well as technology. The technical ability of the Royal Navy at best was a 
necessary condition for naval aviation. But the sufficient conditions for the emergence of the Naval Air Service were the specific threats and objectives which were set for the Navy, by the international environment as mediated by the Cabinet, the C.I.D. and senior levels in the Admiralty.

If this is a reasonable conclusion from the evidence, then two concluding observations may be made, practical and theoretical and negative and positive, with respect to the cogency of the field of Military Innovation Theory

As has been emphasised in Part I, Military Innovation Theory, as evaluated in this dissertation, has a strong functionalist ethos. It is not intended to be the pursuit of knowledge per se but is aimed at improving military effectiveness. Unfortunately, the evaluation above most favours two approaches which are probably the least 'operational' of the four considered. By definition the Civil-Military model is outside the control of the military, and not entirely in the control of the civil authorities either since they are seen as responding to the structure of international relations (i.e. defence threats and opportunities). The cultural approach, which in this case is aligned with training and education, is within the control of military authorities. In principle, at least, personnel can be trained to be adaptable and forward looking. But the argument in the preceding paragraph is that these qualities can only facilitate innovation - may indeed be necessary for innovation - but from the multiplicity of possibilities cannot by themselves select and promote a military innovation.

On the other hand, from the theoretical point of view, this example of military innovation sits fairly comfortably in one authoritative summation of the respective roles of neo-realism and cultural theories. According to Desch, as far as the security field is concerned (i.e. embracing international relations and military history and strategy), the divide between the two has a long history dating from, at least, Thucydides. ${ }^{161}$ His history of the Peloponnesian wars instanced both cultural- and realist-conditioned behaviour in the complex struggle between Athens and Sparta. ${ }^{162}$ Since then, according to Desch, various 'waves' of culturalism have come and gone, two alone in the period since World War II with a third still in spate. For various reasons, theoretical and empirical, Desch concludes that cultural theories, '... by themselves, do not provide much additional explanatory beyond existing theories'. While accepting that culture matters, he sees cultural theory occupying a role subsidiary to realism, helping to explain occasional anomalies thrown up by the historical record.

This would be a fair judgement of the relative values of the Civil-Military and Cultural models as exemplified in the development of British naval aviation 1908-14. 


\footnotetext{
${ }^{1}$ Unless specifically to the contrary, the expression 'military' refers to all branches of armed forces: army, navy, air force, marines.

${ }^{2}$ Adam Grissom, 'The future of military innovation studies', in Journal of Strategic Studies, xxix ( 2006), p. 919.

${ }^{3}$ Stephen P. Rosen, 'New ways of war: understanding military innovation' in International Security, xiii (1988), p.138.

${ }^{4}$ However, a useful academic survey is given in Girish Luthra, 'Military innovation: hurdles, bumps and jumps', in Strategic Analysis, xxvii (2003), pp 564-567. See also Michael Howard, 'Military science in the age of peace', in Journal of the Royal United Services Institution, cxix (1974,) pp 3-11.

${ }^{5}$ Terry Terriff and Theo Farrell, 'Military change in the new millennium', in Theo Farrell and Terry Terriff (eds), The sources of military change: culture, politics and technology (London, 2002), p.265.

${ }^{6}$ Geoffrey Till 'Foreword' in Richard Harding, Royal Navy 1930-2000. Innovation and Defence, (London: Routledge, 2005), p. xiii.

${ }^{7}$ Richard Hallion reflecting a probable consensus lists the four great technological advances of the First World War as tanks and radio communication as well as the submarine and aeroplane. Significantly, three of the four affect the Navy and tanks were also originated by the Navy. Richard P. Hallion 'World War I: an air war of consequence', in Endeavour, xxxviii (2014), pp 77-90.

${ }^{8}$ Walter Raleigh, The War in the Air Being the Story of the Part Played in the Great War by the Royal Air Force, I (London, 1922), p. 1.

${ }^{9}$ Arthur J. Marder, From the Dreadnought to Scapa Flow, i: The road to war 1904-1914 (Barnsley, 2013), pp 333-4.

${ }^{10}$ Grissom, 'The future of military innovation studies', p. 907.

${ }^{11}$ Jon Tetsuro Sumida and David Alan Rosenberg, 'Machines, men, manufacturing, management and money: the study of navies as complex organisations and the transformation of twentieth century naval history', in John B. Hattendorf, (ed.), Doing naval history: essays towards improvement (Newport, 1996), p.35.

${ }^{12}$ Robert Jervis, 'Navies, politics and political science', in Hattendorf, (ed.), Doing naval history, p.47.

${ }^{13}$ Jon Tetsuro Sumida, 'Expectation, adaptation and resignation: British battle fleet tactical planning August 1914-April 1916', in Naval War College Review, Ix (2007), p. 102.

${ }^{14}$ Julian S. Corbett, History of the Great War: naval operations, I: To the battle of the Falklands December, 1914 (London, 1920). Raleigh, The war in the air. Marder, From the Dreadnought to Scapa Flow.

${ }^{15}$ Sumida and Rosenberg, 'Machines, men, manufacturing, management and money', in Hattendorf, (ed.), Doing naval history, pp 28-9.

${ }^{16}$ Nicholas Lambert, Sir John Fisher's naval revolution (Columbia, 2002). Jon Tetsuro Sumida, In defence of naval supremacy, finance, technology and British naval policy 1889-1914 (London, 1993). It should be added that some of Sumida and Lambert's approaches have proved controversial with respect both to findings and methodology. With respect to findings see Christopher Bell, Churchill and Sea Power (Oxford, 2012) and Christopher Bell, 'Sir John Fisher's Naval Revolution Reconsidered: Winston Churchill at the Admiralty, 1911-14', in War in History, xviii (2011), pp. 333-56. With respect to methodology see Matthew S. Seligman in 'The renaissance of pre First World War naval history', in Journal of Strategic Studies, xxxvi (2013), pp 454-79.

${ }^{17}$ Sumida and Rosenberg, 'Machines, men, manufacturing, management and money' in Hattendorf, (ed.), Doing naval history, p.32.

${ }^{18}$ Williamson R. Murray and Alan R. Millet (eds), Military Innovation in the Interwar Period (Cambridge, 1998). H.R. Winton and D. R. Mets (eds), The challenge of change 1918-41 (Lincoln, 2000). Richard Harding (ed.), The Royal Navy 1930-2000: innovation and defence (London, 2005). Bryan Ranft, Technical change and British naval policy 1860-1939 (London, 1977). .

${ }^{19}$ Barry Posen, Sources of Military Doctrine; France, Germany and Britain between the Wars (Ithaca, 1984).

${ }^{20}$ Grissom, 'The future of military innovation studies', p. 906.
} 
${ }^{21}$ An example is Jeffrey Isaacson, Christopher Layne, and John Arquilla, Predicting Military Innovation (Santa Monica, 1999). The authors are researchers working for the RAND corporation, a prominent defence contractor.

${ }^{22}$ Geoffrey Till, 'Foreword', in Harding (ed.), The Royal Navy 1930-2000, pp xiii-xiv.

${ }^{23}$ Stephen Rosen, Winning the next war: innovation and the modern military (Ithaca, 1991), p. 22.

${ }^{24}$ R. D. Layman, Naval aviation in the First World War: its impact and influence (London, 1996), p.8.

${ }^{25}$ Eric Grove, 'Seamen or Airmen', in Tim Benbow (ed.), British naval aviation: the first 100 Years (London, 2011).

${ }^{26}$ S. W. Roskill, (ed.), Documents relating to the naval air service, i, 1908-18 (London, 1969)

${ }^{27}$ For example, Ruddock F. Mackay, Fisher of Kilverstone (London, 1973). Winston S. Churchill, The Great Crisis 1911-1919 (New York, 2005). John Arbuthnot Fisher, Memories (London, 1919). Randolph S.

Churchill, Winston S. Churchill, ii, The Young Statesman 1900-1914 (Cambridge, 1967). Reginald Bacon, From 1900 Onwards (London, 1940). Murray Sueter, Airmen or Noahs: fair play to our airmen: the great Neon myth exposed (London, 1928).

${ }^{28}$ Richard Bell-Davies, Sailor in the air: the memoirs of the world's first carrier pilot (London, 1967). A.M. Longmore, From sea to sky: memoirs 1910-45 (London, 1946), C.R. Samson, Fights and flights: a memoir of the Royal Naval Air Services (London, 1930).

${ }^{29}$ Hezlet, Arthur, Aircraft and sea power (London, 1970), Robert Jackson, Strike from the sea (London, 2009) and David Wrags, Wings over the sea: a history of naval aviation (Newtown Abbott, 1979).

${ }^{30}$ For example: C. F. Snowden Gamble, The story of a North Sea air station (London, 1928). Horace Frederick King, Armament of British aircraft 1909-39 (London, 1962). Peter M. H. Lewis, British aircraft 1809-1914 (London, 1962), Bill Gunston, Chronicle of aviation (Chalfont, 1992).

31 Theodore Waltz, Theory of international politics (New York, 1979).

32 Barry Posen, Sources of military doctrine; France, Germany and Britain between the Wars (Ithaca, 1984), p. 223.

${ }^{33}$ The 'mavericks' in question were Hugh Dowding in Britain and Hans Guderian in Germany.

${ }^{34}$ Adam Grissom, 'The Future of Military Innovation Studies', in the Journal of Strategic Studies, xxix (2006), pp 905-34.

${ }^{35}$ Grissom, 'The Future of Military Innovation Studies', pp 905-934.

${ }^{36}$ Stephen P. Rosen, Winning the next war: innovation and the modern military (Cornell, 1991) and 'New ways of war: understanding military innovation theory', in International Security, xiii (1988), pp 143-68.

${ }^{37}$ Grissom, 'The Future of Military Innovation Studies', pp 905-34.

38 Idem, p. 916.

${ }^{39}$ Elizabeth Kier, Imagining war: French and British doctrine between the wars (Princeton, 1997) and Kier, 'Culture and military doctrine: France between the wars', in International Security, xix (1995), pp 65-93.

${ }^{40}$ Theo Farrell 'World culture and the Irish Army', in Theo Farrell and Terry Terriff (eds), The sources of military change: culture, politics and technology (London, 2002), pp 69-90.

${ }^{41}$ Robert E. Mullins, 'Sharpening the Trident: the Decisions of 1889 and the Creation of Modern Seapower' (Ph.D. thesis, Kings College, London, 2000).

42 Grissom, 'The Future of Military Innovation Studies', pp 919-24.

43 Theo Farrell, 'Improving in war: military adaptation and the British in Helmand, 2006-2009' and James A Russell, 'Innovation in the crucible of war in Anbar and Ninewa, Iraq, 2005-2007', both in Dima Adamsky and Kjell Inge Bjerga, Contemporary military innovation: between anticipation and adaptation (Oxford, 2012). .

${ }^{44}$ Thomas S. Kuhn, The structure of scientific revolutions (Chicago, 1962).

${ }^{45}$ Alfred Gollin, An island no more: Britain and the Wright brothers 1902-09 (London, 1984). The first commercial use of aeroplanes did not occur until 1911 in Britain when regular post was carried from Hendon to Windsor. P. Lewis, British aircraft 1809-1914 (London, 1962), p. 29.

${ }^{46}$ Christina Goulter, 'The Royal Naval Air Service: a very modern force', in S. Cox and P. Gray (eds), Air power history (London, 2002), p.61.

${ }^{47} \mathrm{C}$. F. Snowden Gamble, The air weapon: being the account of the growth of British military aeronautics from the beginnings in the year 1783 until the end of the year 1929 (Oxford, 1931), pp 15-23. 
${ }^{48}$ R. D. Layman, Before the aircraft carrier: the development of aviation vessels 1849-1933 (London, 1989), p.31.

${ }^{49} \mathrm{Gamble}$, The air weapon, pp 48-49 and p.55. The Paris balloons were used for communication rather than observation and were manned by sailors. Both sides of the U.S. civil war used balloons tethered to vessels. R. D. Layman, Naval aviation in the First World War: its impact and influence (London, 1996), p. 42 , p. 47.

50 Layman, idem, pp 44-45.

${ }^{51}$ Walter Raleigh, The war in the air, $i$ (London, 1922), pp.77--92. Relative is the key word. Raleigh gives a list showing that 13 of the first 25 Zeppelins were destroyed by accident sometimes with severe loss of life.

52 Gamble, The air weapon, p.74.

${ }^{53}$ Memorandum by Captain Bacon, Director of Naval Ordnance for construction of an airship. 27 July 1908. T.N.A. Air $1 / 2328$

${ }^{54}$ David Hobbs, 'Her Majesty's rigid airship No 1', in The Navy, Ixxi (2009), pp 26-31.

55 Technical Sub-Committee of the Committee on Imperial Defence. Airships. Report by Captain Sueter and Mr Mervyn O'Gorman, 16 July 1912. T.N.A. Air 1/2100.

${ }^{56}$ Brian Inglis, 'John W. Dunne (1875-1949)' in (Oxford Dictionary of National Biography)

http://www.oxforddnb.com.jproxy.nuim.ie/view/article/32055?docPos=1 (Accessed 4 April 2015.)

John S. Bagley, 'Samuel F. Cody. (1861-1931)' in Oxford Dictionary of National Biography

http://www.oxforddnb.com.jproxy.nuim.ie/view/article/32055?docPos=1 Accessed 4 April 2015.)

57 Percy B Walker, Early aviation at Farnborough, ii: The first aeroplanes (London 1974), pp 120-7. The longest flight was 1,390 feet.

${ }^{58}$ Phillip Jarret, Frank McLean godfather to British Naval Aviation (Barnsley, 2012).

59 Peter Reese, The men who gave us wings: Britain and the aeroplanes 1796-1914 (Barnsley, 2014), pp 197-210

60 Philip Jarrett, Frank McClean: Godfather to British naval aviation. (Seaforth Publishing, 2011), pp61-62

${ }^{61}$ Admiralty letter to Treasury requesting funding for naval air service, 20 January 1912.. T.N.A. Adm $116 / 1275$.

62 This list is on the basis of stations with aircraft on the eve of war. In fact some other sites were designated as air stations but only received aircraft after the outbreak of hostilities. A list of His

Majesty's naval aircraft, July 1914. T.N.A. Air 1/626/17/46.

${ }^{63}$ Strictly speaking, it was the first vessel completed as an aeroplane carrier: the vessel was already under construction as a merchant ship when the Admiralty bought it for naval aviation.

${ }^{64}$ A list of His Majesty's naval aircraft, July 1914. T.N.A. Air 1/626/17/46.

${ }^{65}$ Azar Gat, "The "revolution in military affairs" (RMA) as an analytical tool for the interpretation of military history', in D Adamsky and K. J. Bjerga (eds), Contemporary military innovation (London, 2012), pp 8-9.

${ }^{66}$ http://www.wright-brothers.org/Information Desk/Just the Facts/Airplanes/Flyer I.htm. Accessed 7 April 2015.

${ }^{67}$ Layman, Before the aircraft carrier, p.16, pp 107-111..

${ }^{68}$ Eric Grove 'Seamen or airmen? The early days of British naval flying' in Tim Benbow (ed.), British naval aviation: the first 100 years (London, 2011), p.7.

${ }^{69}$ This and the next two paragraphs draw on Michael Paris, Winged warfare: the literature and theory of aerial warfare in Britain, 1859-1917 (Manchester, 1992), pp 65-123 and Alfred Gollin, No longer an island: Britain and the Wright brothers 1902-09 (London, 1984), pp 315-91.

${ }^{70}$ Neville Jones, The origins of strategic bombing (New York, 1973), pp 28-29 for an account of the Aerial League's lobbying.

${ }^{71} \mathrm{H}$. G. Wells, The war in the air (London, 1908). For a sample of the literature see Michael Paris, 'Fear of flying: the fiction of war 1886-1916' in History Today, xxxiii (1993), pp 29-35. Stephen Budiansky, Air power (London, 2005), pp 39-40.

72 Paris, Fear of flying, p. 33. 
${ }^{73}$ Report and proceedings of a sub-committee of the Committee on Imperial Defence on aerial navigation, 28 January 1909. T.N.A. Air 1/2100 (hereafter 'Report of the sub-committee on aerial navigation 1909').

74 Percy B. Walker, Early aviation at Farnborough, ii: the first aeroplanes (London, 1974), p. 323-8.

75 Gollin, No longer an island, p. 415

${ }^{76}$ Report of the sub-committee on aerial navigation 1909. T.N.A. Air 1/2100.

${ }^{77}$ Report of the sub-committee on aerial navigation 1909. Appendix II Memorandum of the War Office on progress in aerial navigation. T.N.A. Air 1/2100. The memorandum noted that the Germans had not signed the Second Hague Convention banning the bombardment of cities from balloons.

${ }^{78}$ Gollin, No longer an island, p. 395. Budiansky, Air power, p.41

79 Note: this should not be confused with the Royal Air Force, established in 1918.

80 'John William Strutt, Third Baron Rayleigh (1842-1919', in Lord Rayleigh-biographical. (Nobelprize.org. http://www.nobelprize.org/nobel_prizes/physics/laureates/1904/strutt-bio.html.) Accessed 20 March 2015.

${ }^{81}$ Christoper Shores, 100 years of British naval aviation (Yeovil, 2009), p.14

82 David Edgerton, England and the aeroplane an essay on a militant and technological nation (London 1991) pp 8-10.

83 Budiansky, Air power, pp 36-7.

${ }^{84}$ Aerial Navigation. Note by Lord Esher 6 October 1910. T.N.A. Air 1/2311/221/32.

${ }^{85}$ Report of the Standing Sub-Committee of the Committee on Imperial Defence on Aerial Navigation. 27 February 1912. T.N.A. Adm 116/1275.

${ }^{86}$ William Kuhn, 'Charles Rumney Samson (1883-1931) ', in Oxford Dictionary of National Biography http://www.oxforddnb.com.jproxy.nuim.ie/view/article/32055?docPos=1 ) Accessed 19 March 2015.

${ }^{87}$ Even Sir John Nicholson, C.I.G.S, who was dismissive of aeroplanes in 1909, had now been converted. Andrew Whitmarsh, 'British army manoeuvres and the development of military aviation 1910-1913', in War in history, xiv (2007), pp 325-46, p. 326.

${ }^{88}$ Adm 116.1275.

89 D. Hobbs, 'HM's Rigid Airship No 1', in The Navy: the magazine of the Navy League of Australia, Ixxi (2009), pp 26-31.

90 S. W. Roskill (ed.), 'Extracts from minutes of $116^{\text {th }}$ meeting of the C.I.D. on 25 April 1912', in

Documents relating to the Naval Air Service (London, 1969), pp 39-40.

91 Technical sub-committee of the Committee of Imperial Defence on aerial navigation. Airships. Report by Captain Murray Sueter and Mr Mervyn O'Gorman on continental airships. 16 July 2012. T.N.A. Air $1 / 2100$.

${ }^{92}$ Arthur J. Marder, From the Dreadnought to Scapa Flow, i: The approach to war 1904-1914 (Barnsley, 1961),pp 336-7.

${ }^{93}$ Report and proceedings of the technical sub-committee of the Committee on Imperial Defence on aerial navigation. Airships. 30 July 1912. T.N.A. Air $1 / 2100$

${ }^{94}$ Roskill (ed.), 'Extracts from minutes of 122nd Meeting of the CID, 6 February 1913 in Documents relating to the Naval Air Service, p. 84.

${ }^{95}$ R. D. Layman, Naval aviation in the First World War: its impact and influence (London, 1996), pp 67-8.

${ }^{96}$ James N. Pugh, 'The conceptual origins of the control of the air: British military and naval aviation, 1911-1918' (Ph. D. thesis, University of Birmingham, Birmingham, 2012), p. 125.

${ }^{97}$ Letter from Rear Admiral Charles Ottley, Secretary to theC.I.D.to Admiral Price Louis Battenberg, First Sea Lord, 18 January 2012. T.N.A. Air $1 / 626$

98 Paper by Rear Admiral Troubridge, Chief of Naval Staff. The development of naval aeroplanes and airships. 23 January 2012. T.N.A. Air 1/626/17/46.

${ }_{99}$ Marder, From the Dreadnought to Scapa Flow, p.330.

${ }^{100}$ Roskill (ed.), 'Paper by Captain Murray F. Sueter, Director of the Air Department, Admiralty, 29 August 1912' in Documents relating to the royal naval air service, p.57.

${ }^{101}$ First annual report of the Air Committee on the progress of the Royal Flying Corps, 7 June 1913' . T.N.A. Air 1/2311/221/32. Christina Goulter, 'The Royal Naval Air Service: a very modern force', in S. Cox and P. Gray (eds), Air power history (London, 2002), p.53. 
${ }^{102}$ Robin D. S. Higham, The British rigid airship, 1908-1931: a study in weapons policy (Foulis, 1961)

${ }^{103}$ Theo Farrell and Terry Terriff, 'The source of military change' in Theo Farrell and Terry Terriff The sources of military change: culture, politics and technology (Boulder, 2002), p. 9. Dimo Adamsky and K. J. Bjerga, 'Introduction to the information-technology revolution in military affairs', in Journal of Strategic Studies, xxxiii (2010) pp 463-8. Katharina Holzinger and Christoph Knill, 'Causes and conditions of crossnational policy convergence', in Journal of European Public Policy, xii (2005), pp 775-96.

104 James N. Pugh, 'The conceptual origins of the control of the air: British military and naval aviation, 1911-1918' (Ph.D. thesis, University of Birmingham, Birmingham, 2012), pp 154-5.

${ }^{105}$ Arthur Marder From the Dreadnought to Scapa Flow, i: The road to war 1904-1914 (Barnsley, 2013), p. 402.

${ }^{106}$ Christina Goulter, Forgotten offensive: Royal Air Force Coastal Command's anti-shipping campaign 1940-45 (London, 1995), pp 8-9

${ }^{107}$ As exemplified in Letter from Read Admiral Ottley, secretary of the C.I.D to Admiral Louis Battenberg, First Sea Lord, 16 January 1912. T.N.A. Air $1 / 626$

${ }^{108}$ For an optimistic view see Paper on aeroplanes for naval service, January 1912 by Lieutenant H. A. Williamson. T.N.A. Air 1/626/17/46. But for a more realistic view see Letter to Admiralty from Rear Admiral Tupper President of the Submarine Committee reporting on results of experiments with aeroplanes for scouting for submarines. T.N.A. Air 1/626/17/46.

109 In practice it proved quite useful for aeroplanes to spot submarines on the surface since this prompted them to dive and prevent them from manoeuvring into a position to attack.

${ }_{110}$ Paper on aeroplanes for naval service. T.N.A. Air 1/626/17/46.

${ }^{111}$ Horace Frederick King, Aeromarine origins : the beginnings of marine aircraft, winged hulls, aircushion and air-lubricated craft, planing boats and hydrofoils (London, 1966), p.31.

${ }_{112}$ Donald Maclntyre, Wings of Neptune: the story of naval aviation (London, 1963), pp 3-4.

113 Peter M. H. Lewis British aircraft 1809-1914, p. 439. Coincidentally Fabre's take off was also his first flight and also ended in a crash.

${ }^{114}$ Christopher Shores, 100 years of British naval aviation (Yeovil, 2009), p.15.

115 R. D. Layman, Before the aircraft carrier: naval aviation vessels 1849-1922 (London, 1989), pp 107-10

${ }^{116} \mathrm{~S}$. W. Roskill (ed.),, 'Royal Naval Air service training manual, Air Department, Admiralty, November 1914 ', in Documents relating to the Naval Air Service 1908-18 (London, 1969), pp 68-69

${ }^{117}$ Launching ramps also affected the working of capstans and upset ships' stability. Rotating platforms, introduced during the war eased some of these problems. R. D. Layman, Naval aviation in the First World War: it impact and influence (London, 1996), p. 34.

118 Lewis, British aircraft 1809-1914, p. 440.

${ }^{119}$ Goulter, Forgotten offensive, p.5

${ }^{120}$ Brad King, Royal Naval Air Service 1912-18 (Aldershot, 1997), p. 9

${ }^{121}$ Richard Bell-Davies, Sailor in the air (London, 1967), pp 81-2.

${ }^{122}$ Report of Captain of Hermes on Aircraft During Manoeuvres Annex I, in Report on Manoeuvres by the Umpire in Chief, 1913, pp 82-86. T.N.A. Air 1/626/17/46.

${ }^{123}$ The downed aeroplane was picked up by a passing merchantman which generously gave it passage in the general direction of the fleet and duly handed it over when it encountered HMS Hermes. Ironically, the merchantman was German.

${ }^{124}$ Report of the Standing Sub-Committee of the C.I.D on Aerial Navigation 1909. T.N.A. Air 1/2100

${ }^{125}$ Report of the Committee on rendering oil fuel tanks, etc. invisible. April 1914.T.N.A. Air 1/626.

${ }^{126}$ Robert Jackson Strike from the sea (London, 2009), p 19. The First Annual report of the Air Committee on the Progress of the Royal Flying Corps, 7 June 1913. T.N.A. Air 1/2311/221/32

${ }^{127}$ Cited by Horace F. King, Armament of British aircraft 1909-39 (London, 1962), p.320

${ }^{128}$ Macintyre, Wings of Neptune, p.7

${ }^{129}$ Eric Grove, 'Seamen or Airmen' in Tim Benbow (ed.), British naval aviation: the first 100 Years (London, 2011), pp 25.

${ }^{130}$ Goulter, Forgotten offensive, p.7.

${ }^{131}$ Group Captain R.H. Hall Early bomb armament experiments. T.N.A. Air 1/725, 118/1.

132 Goulter, Forgotten offensive, p.4. 
${ }^{133}$ Murray Sueter, Airmen or Noahs: fair play to our airmen: the great Neon myth exposed (London, 1928), p. 49. Sueter's application for the patent release gear is appended to this largely autobiographical book.

${ }^{134}$ Roskill (ed.), 'Extract from Minutes of C.I.D. Sub-Committee on Allotment and Location of Seaplane and Aeroplane Stations, 25 June 1914', in Documents relating to the Royal Naval Air Service, pp 148-55.

$135 \mathrm{King}$, Armament of British aircraft, p.307. However, another account suggests the first drop was by a Shorts civilian test pilot Gordon Bell the day before Longmore's drop. C. H. Barnes, Shorts Aircraft since 1900 (London, 1989), p. xi.

${ }^{136}$ A. M. Longmore, From Sea to sky: memoirs 1910-45 (London, 1946), p.36. The eventual effective torpedo-carrying aircraft was the Sopwith Cuckoo.

${ }^{137}$ King says that there were four other Shorts aeroplanes of the same type as Longmore's ready for torpedo dropping. King, Armament of British aircraft, p.307.

138 Bell-Davies, Sailor in the air, p.88

${ }^{139}$ Report of the sub-committee of the Committee on Imperial Defence on aerial navigation. 28 January 1909. Appendix II, pp 83-91. T.N.A. Air 1/2100 containing replies from six senior officers to a circular from the C.I.G.S.

${ }^{140}$ See David Edgerton, England and the aeroplane: an essay on a militant and technological nation (London 1991), pp 4-13 for an account of the full extent of Haldane's reforms in relation to aviation. ${ }^{141}$ And occasionally coming down with a bump with them. On at least two occasions Churchill's aeroplanes were downed in the sea and Churchill had to be rescued. Gordon Kinsey, SeaplanesFelxistowe (Lavenham, 1978), pp. 4-5.

142 S. W. Roskill (ed), 'Extract from minutes of $120^{\text {th }}$ meeting of the C.I.D. on 6 December 1912' in Documents relating to the Royal Naval Air Service (London, 1969), p. 65.

${ }^{143}$ Arthur J. Marder, From the Dreadnought to Scapa Flow, i: The road to war 1904-14 (Barnsley, 1961), pp 336-8.

${ }^{144}$ In fact, overly so: in 1909 Zeppelins were reported everywhere in Britain though it is known that at the time of the reports that the few airships that Germany possessed were in Germany. See e.g. Stephen Budiansky, Air power (London, 2004), p. 41.

145 notably the first cross-channel flight and the first flight from London to Manchester.

146 Peter Reese, The men who gave us wings: Britain and the aeroplanes 1796-1914 (Barnsley, 2014), p. p 167.

147 Eric Grove, 'Seamen or Airmen' in Tim Benbow (ed.), British naval aviation: the first 100 Years (London, 2011), pp 21-5.

148 Peter Kemp, 'Murray Sueter 1872-1960' in Oxford Dictionary of National Biography http://www.oxforddnb.com.jproxy.nuim.ie/view/article/36368?docPos=1 (Accessed 19 May 2015). Murray Sueter, Airmen or Noahs: fair play to our airmen: the great Neon myth exposed (London, 1928).

149 Jon Tetsuro Sumida, In defence of naval supremacy, finance, technology and British naval policy 18891914 (London, 1993), pp 329-38.

150 These were the Blériot Experimental ('BE'); Scouting Experimental ('SE'); Farman Experimental ('FE'); and the 'Reconnaissance Experimental ('RE') series of aircraft. One of the SE series held the world air speed record in 1914.

${ }^{151}$ Christina Goulter, 'The Royal Naval Air Service: a very modern force' in S. Cox and P. Gray (eds), Air power history (London, 2002), p.61-3.

152 Peter Rosen, Winning the next war: innovation and the modern military (Ithaca, 1991), p.20.

153 Under Churchill there were three First Sea Lords (Wilson, Bridgeman and Battenberg) in the period 1910 to 1914 whose average tenure was therefore less than 18 months. None were allowed much room for independent action by Churchill. Marder, From the Dreadnought to Scapa Flow, p. 255. In 1914 Fisher returned, only to depart over the Dardenelles campaign the following year.

${ }^{154}$ Christina Goulter, Forgotten offensive: the Royal Air Force Coastal Command anti shipping campaign 1940-45 (London, 1995), pp. 6-9.

155 Goulter, 'The Royal Naval Air Service: a very modern force', p. 61.

156 Neville Jones, The Origins of strategic bombing (London, 1973), pp 40-9. 
${ }^{157}$ First annual report of the Air Committee on progress of the Royal Flying Corps, June 1913, pp 7-8. Second annual report of the Air Committee on progress of the Royal Flying Corps, 1 May 1914, p.11. 1 May 1914.T.N.A. Air 1/2311/221/32.

158 Marder, From the Dreadnought to Scapa Flow, pp 28-36.

${ }^{159}$ Even to the extent of developing weapons for the Army. The R.N.A.S. pioneered the use of armoured cars in Belgium in 1914, and later the Navy progressed the tank project for some time in the face of Army apathy. C. R. Sampson was involved in the development of the armoured car and Murray Sueter in the early stages of the development of the tank.

${ }^{160}$ See review of literature in James N. Pugh, 'The conceptual origins of the control of the air: British military and naval aviation, 1911-1918' (Ph. D. thesis, University of Birmingham, Birmingham, 2012), pp 154-169.

${ }^{161}$ Michael C. Desch, 'Culture class: assessing the importance of ideas in security studies' in International Security, xxii (1998), pp 141-70, (The even earlier exponent was Sun Tzu (544-496 BC)).

162 The Melian dialogues in Thucydides, History of the Peloponnesian War, translated by Warner, R., (London, 1954), pp 400-08. 